\title{
Debt, Recovery Rates and the Greek Dilemma *
}

\author{
CAE Goodhart† MU Peiris; DP Tsomocos ${ }^{\S}$
}

April 13, 2017

\begin{abstract}
Most discussions of the Greek debt overhang have focussed on the implications for Greece. We show that when additional funds released to the debtor (Greece), via debt restructuring, are used efficiently in pursuit of a practicable business plan, then both debtor and creditor can benefit. We examine a dynamic two country model calibrated to Greek and German economies and support two-steady states, one with endogenous default and one without, depending on creditors' expectations. In the default steady state, debt forgiveness lowers the volatility of both German and Greek consumption whereas demanding higher recovery rates has the opposite effect. In a second order approximation of the model, conditional welfare analysis shows that a policy of immediate leniency followed by harsher terms as the economy grows is beneficial to both creditors and debtors.
\end{abstract}

*We would like to thank two anonymous referees, the participants of the 2015 SAET conference, 2016 ICEF NRU HSE research seminar, 2016 Oxford Said Business School conference, LSE SRC, Bank of England, Koc University, National Bank of Austria, 4th International Conference on Sovereign Bond Markets at NUS, Sumru Altug, Alexis Belianin, Alexei Boulatov, Emiliano Catonini, John Geanakoplos, Roman Horvath, Serkan Imisiker, Ken Iwatsubo, Christian Julliard, Christoffer Koch, Tryphon Kollintzas, Reinhard Neck, Ken Okamura, Athanasios Orphanides, Han Ozsoylev, Herakles Polemarchakis, David Rappaport, Abdelaziz Rouabah, Christoph Siebenbrunner, Daniele Siena, Martin Summer, Gregory Thwaites, Peter Tufano, Kamil Yilmaz, Alexandros Vardoulakis, Vagelis Vassilatos, Kieran Walsh, and especially Heather Gibson. Peiris was funded within the framework of the Basic Research Program at the National Research University Higher School of Economics (HSE) and by the Russian Academic Excellence Project '5-100'.

${ }^{\dagger}$ London School of Economics and FMG

${ }^{\ddagger}$ ICEF, NRU Higher School of Economics, Moscow

$\S$ Said Business School and St Edmund Hall, University of Oxford 
Keywords: Debt, Default, Renegotiation, Business Cycles, Open Economy. JEL Classification: F34 G15 G18

\section{Introduction}

In this paper we examine the interaction between a set of debtors, whom we characterize as Greeks, and a set of creditors, whom we term Germans. We outline the circumstances that may make the Greek debtors choose to renege, to default, on an (unsecured) portion of their debt, dependent on the various costs which such default entails. The costs and benefits of default are quite complex, and we have modelled these carefully.

In our model, creditors (Germans) can be more or less tough, (forgiving being the inverse of tough), in imposing penalties on the defaulting Greeks. We model this as a 'recovery' rate, whereby the German creditors can grab, and use for themselves (i.e. recover), a larger share (a higher recovery rate), of the underlying defaulted assets.

Most of the debate on the costs/benefits of default and renegotiation have primarily focussed on the effects and trade-offs for the debtors (Greeks), while the effects on creditors have largely been ignored, or assumed to be negative

${ }^{1}$. The language of the discussion has been couched within the framework of a "zero-sum" game, and in other words the assumption that any debt relief to Greece must entail a (net present value) transfer of resources from creditors.

What we show is that, under a set of plausible conditions, greater forgiveness (a lower recovery rate) by the creditors currently can benefit both debtors

\footnotetext{
${ }^{1}$ See Zettelmeyer et al. (2013), Ardagna and Caselli (2014) and Broner et al. (2014) for analysis of Greek restructuring episodes since 2010.
} 
and lenders. These conditions include reasonable prospects for the profitability of future investment by the debtors (in Greece) and a willingness of the debtors to apply available funds to such investment. If these conditions hold, then the short-term loss to the creditors (Germans) from being more forgiving would be more than matched by longer-term higher returns from their remaining investments in Greece, and an overall lower volatility of German consumption (welfare). In our model, temporary negative productivity shocks are amplified and propagated through financial sector instability (default). That Greek output has been below its potential is reflected, at the very least, by the $25 \%$ contraction witnessed over the last seven years. ${ }^{2}$

The events of 2009 brought a major change in Greece's economic conditions. ${ }^{3}$ Several different factors contributed to the onset of the crisis in 2009, including increased credit spreads, a collapse of demand globally, and, most importantly, the realisation that the twin deficits and the national Debt-to-GDP ratio were unsustainable. ${ }^{4}$ We argue that, in addition to the issues described in Gourinchas et al. (2016), the economic fundamentals of the Greek economy did not suddenly change in 2009, rather, expectations were destabilised. Consequently creditor's expectations about the ability of Greeks to honour their contractual obligations radically changed, and, therefore, credit-spreads

\footnotetext{
${ }^{2}$ Greece's growth rates were often in excess of $10 \%$ during the 1950 s, resembling those of modern tiger economies in the late 1990s. Likewise, industrial production increased at a rate of $10 \%$ during much of the 1960s. Greece consistently outperformed most European economies for most of the second world war period. See Bitzenis et al. (2015) for an extended discussion.

${ }^{3}$ Prior to this, Greece had experienced a prolonged period of economic growth, averaging $5 \%$ year-on-year, since the late 1990s and, furthermore, Greek credit-spreads above German rates were virtually zero. Creditors and investors viewed Greece as a safe, low-risk, investment destination. Reconciling this with what followed is then challenging, particularly from a modelling perspective.

${ }^{4}$ Gourinchas et al. (2016) describes these as the 'Trifecta' of a Sovereign Debt Crisis, Banking Crisis and Sudden Stop.
} 
rose steeply. In addition, a temporary relative decline in productive efficiency, moved the economy from growth and stability to contraction and instability. In our model, we capture these effects by supporting two steady state equilibria. One where default does not occur, and Greece can freely issue debt at the risk-free rate, and another, the one we emphasise, where default and renegotiation occurs.

Formally, we consider a two country RBC model, describing Greece as the debtor nation, and Germany, the main creditor nation. We combine Greek households and government into a single representative household whose individual decisions (especially default) depend on the aggregate activities of the economy. ${ }^{5}$ Greek households can issue both secured and unsecured debt to German households and the possibility of renegotiating on unsecured debt exists. We explicitly model the decision to default and show that, although such default normally exacerbates the volatility of consumption, such volatility may actually be reduced with more lenient debt restructuring terms as the outcome of renegotiation. Put another way, we argue that the key issue is not whether there is a moral duty of creditor nations to transfer resources to Greece, but whether creditors are willing to trade off short-term losses for medium and long-run gains.

In our model debt can be either secured, in which case failure to honour the debt would invoke bankruptcy proceedings which are ruled out, or unsecured, in which case the lender has a limited claim on the existing wealth of the

\footnotetext{
${ }^{5}$ In abstracting from fiscal considerations we focus on how the inefficiencies that default, and the subsequent collective renegotiation, affect the efficiency of the path of capital accumulation. We argue in Section 1.2 that political instability in the country means modelling the economy as a time consistent planner, or even government, does not adequately describe the present Greek reality.
} 
borrower and cannot invoke bankruptcy proceedings. Thus a key feature of the paper is that the possibility of default in equilibrium exists on unsecured debt.

We assume that Greek households can only issue non-state-contingent bonds. Debtors may choose to renege on some of their debt obligations, but then suffer a renegotiation cost. In order to be able to borrow again, they must pay this cost and, in this sense, the decision to default is strategic. If debtors default, they incur a welfare cost in renegotiations proportional to the scale of default.

This cost effectively creates a borrowing constraint and stems from Shubik and Wilson. (1977) and Dubey et al. (2005) and applied in Tsomocos (2003), Goodhart et al. (2005) and Goodhart et al. (2006). In the RBC literature, our model shares similar features to De Walque et al. (2010). Our closest methodological precursors are Peiris and Tsomocos (2015) (which studies a two period large open international economy with incomplete markets and default); Goodhart et al. (2013), which explores the effect of international capital flow taxation on default and welfare in a deterministic two period large open economy; and Walsh (2015a) and Walsh (2015b), which consider default in a small open dynamic incomplete markets economy. In these latter two papers, the marginal cost of default depends on the level of wealth, so the propensity to default depends on business cycle fluctuations. We follow this notion here by introducing a macrovariable that governs the marginal cost of renegotiating debt (default), termed 'credit conditions'. This reflects changing motivations and incentives of debtors to make the necessary sacrifices to repay their obligations, as emphasised by Roch and Uhlig (2016).

Ultimately the non-pecuniary default cost methodology and credit-conditions 
variable allows us to calibrate the model to realised average default/hair-cut rates. We believe that this approach has valid economic grounds and argue that credit-conditions can be adequately captured by an appropriate state variable in order to describe the relationship between loan delinquencies and the capital stock. Meanwhile the debtor country takes the credit-conditions variable as given since creditors are capable of imposing institutional arrangements that are non-negotiable. ${ }^{6}$

German creditors in our model can seize a proportion of defaulted debt. Thus, borrowers effectively incur two additive costs of defaulting: the nonpecuniary cost of renegotiation and a pecuniary punishment via having wealth confiscated. From the point of view of the creditor, the pecuniary seizure of wealth guarantees a minimum repayment rate on debt (possible, for example, due to bargaining power in the renegotiation process). On the other hand, from the point of view of the debtor, the pecuniary cost of default represents a loss of income linked explicitly to default. The literature on sovereign debt has emphasised the long-term impact on output due to default, and in some models this has been described as a direct proportional loss in output ${ }^{7}$. For the sake of simplicity we model the pecuniary cost being enforced in the same date-event that default occurs but our results are robust to having the pecuniary cost spread over several periods, as in Yue (2010). We compare three environments. One where the proportion recovered (recovery rate) is left unadjusted, one where the recovery rate increases, and one where the recovery rate falls. These three environments correspond to potential outcomes follow-

\footnotetext{
${ }^{6}$ Indeed, that was exactly the misconception that contributed to the unsatisfactory attempt to renegotiate the terms of the agreement during the summer of 2015.

${ }^{7}$ See, for example, Asonuma and Trebesch (2016)
} 
ing the debt renegotiation process, and the question we focus on is the effect on the creditors of the three policy alternatives.

Our results are consistent with many of the empirical findings of debt, default and renegotiation outcomes documented in Benjamin and Wright (2013). Specifically as in our model, periods of longer defaults are correlated, and the correlation between output and default is slightly negative with default rates reverting once output has recovered to its trend. They emphasise the importance of debt-renegotiations in default episodes and provide a theoretical basis for it using a Nash-bargaining solution in a small open economy framework, also see Eaton and Gersovitz (1981) and Yue (2010), among others.

\subsection{Greek Debt Crisis Primer}

The major restructuring of debt that occurred in 2012 resulted in a transfer from creditors (including Greek banks and pension funds) to the Greek government of around $€ 100$ billion in present value terms resulting in haircuts of around $60 \%^{8}$. Following these bailouts, and despite a cumulative GDP fall of 25\% between 2009 and 2014, the Greek government cut public primary expenditure by $30 \%$, enacted large disinvestment in the economy, and managed to improve the the fiscal balance from a primary deficit of $10.3 \%$ of GDP into a primary surplus of $0.4 \%^{9}$.

In spite of all these measures, the public debt to GDP ratio continued to climb, resulting in further calls for a bailout. While the IMF argued for sub-

\footnotetext{
${ }^{8}$ See Zettelmeyer et al. (2013) for an excellent analysis of Greek restructuring episodes since 2010.

${ }^{9}$ Bortz (2015)
} 
stantial unconditional restructuring ${ }^{10}$, European creditor nations demanded fiscal consolidation before debt restructuring could be considered ${ }^{12}$. We model this tension by allowing Greek households the opportunity to announce default rates. These default rates are later reduced by creditors demanding a portion to be repaid and represents the present value of fiscal consolidation demanded.

\subsection{Sovereign vs Private Debt}

Since 2008 the distinction between sovereign and private sector debt has become increasingly blurred. On the one hand state support for the banking sector resulted in the accumulation of liabilities by the sovereign through recapitalisation and the national Emergency Liquidity Assistance (ELA) program, while on the other hand the implemented fiscal consolidation policies leave little room for further consolidation and hence fiscal revenues are dependent on national income. Private debt in Greece reached almost $40 \%$ of total gross national debt in 2008. Thereafter it contracted to $20 \%$, with the remainder in both cases being public debt (Figure 1). In particular, after the debt restructuring in 2012 that weakened further the Greek banking system the consequent bank recapitalization considerably increased national debt.

The third pertinent aspect of the crisis is the severe political instability witnessed resulting in 7 legislative elections over 7 years. In the past 5 elections at least four parties have formed a coalition government. To put this into context, all elections in the previous 40 years (other than that of 1989) resulted in a one-party (coalition-free) government.

\footnotetext{
${ }^{10}$ The IMF, in its June 262015 "Preliminary Draft Debt Sustainability Analysis"11 strongly argue for restructuring.

${ }^{12}$ Eurosummit statement SN 4070/15
} 


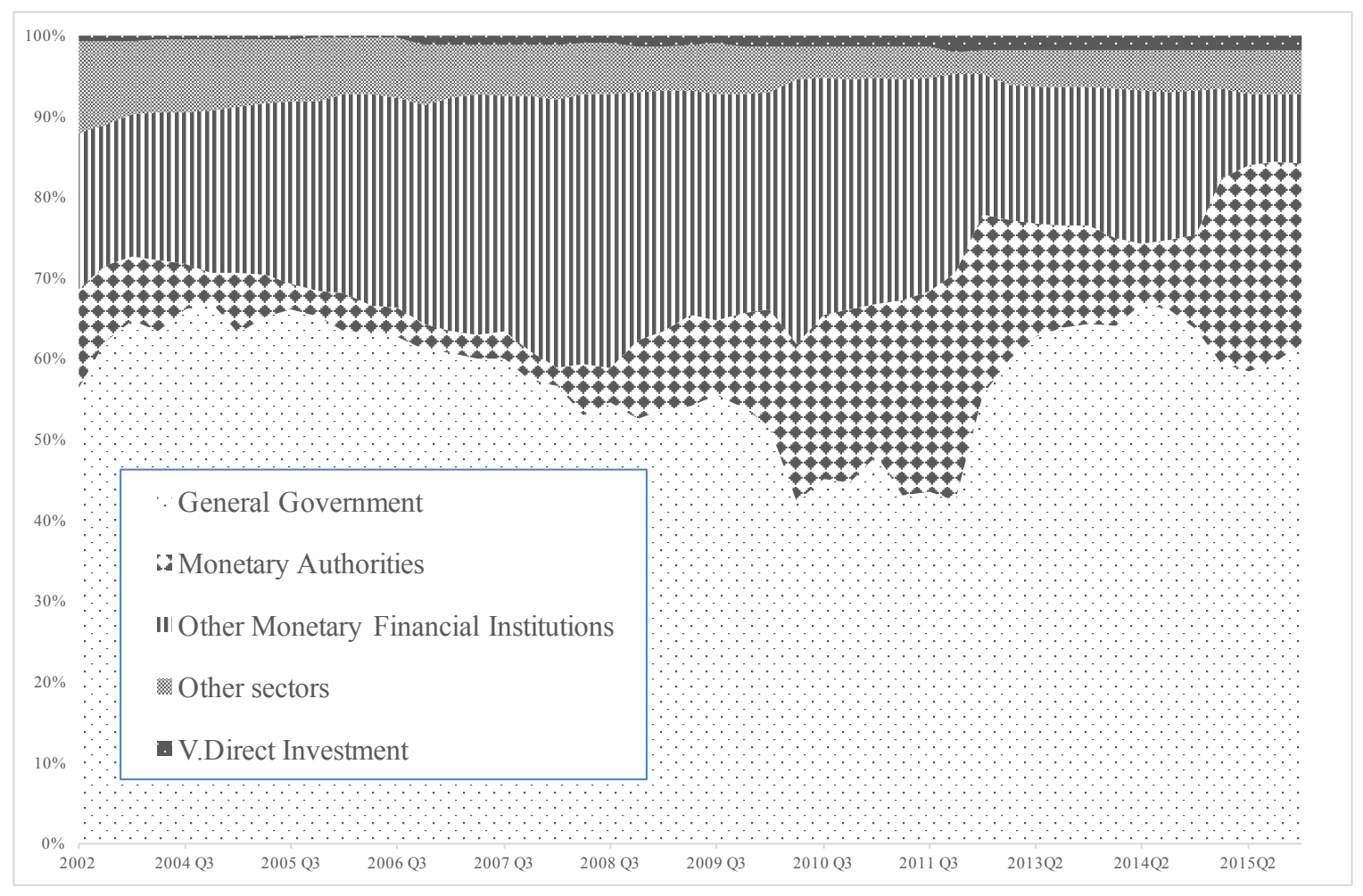

Figure 1: Composition of Gross National Debt.

Composition from 0\% starts with General Government.

Source: Central Bank of Greece data 
These features mean that describing the evolution of Greek national, or even public, debt as the result of an unconstrained planner internalising price effects would miss much of the dependence of national debt on domestic considerations. Furthermore, frequently changing governing parties reflect changing incentives to make sacrifices to make possible repayment of private and public debt (see Sturzenegger and Zettelmeyer (1996)). We therefore model the Greek economy as a decentralised one inhabited by a representative consumer, and so in effect combining the the government and private sector into a single agent. One can think of this as being equivalent to a sequence of planners (or governments) that optimise at each date-event, taking as given actions (and hence prices) in future periods (as there is uncertainty as to which party or parties will be in power, commitment is not possible).

In Section 2 we present the model. In Section 3 we outline the channel through which default operates in the model. Section 4 conducts a 1st order linear approximation of the model and focuses on the volatility of variables

while Section 5 studies the properties of a 2nd order approximation of the model and performs conditional welfare analysis. Finally, Section 7 concludes.

\section{The Model}

Our economy displays the minimum features necessary to highlight the role that an aggregate credit-conditions variable plays in amplifying and propagating financial shocks. There is a representative Greek household which owns and operates a means of production and a large external lender, described as German households. Default generates an effective return differential between 
borrowers and lenders. Lenders receive repayment net of default. On the other hand, borrowers repay their obligations net of default but also incur the private cost of defaulting, the sum of which amounts to the gross of default interest rate. As borrowers require financing for investment in capital, the higher cost of debt caused by default results in a higher required rate of return on capital and hence a lower long-run capital stock.

Formally, the economy consists of 2 countries, Greece (the borrower) and Germany (the lender), each inhabited by a continuum of identical infinitely lived agents. German households receive income from a portfolio of Greek and non-Greek assets. We simplify the nature of income generated from nonGreek assets, so German household decisions which we model should be viewed as the marginal decisions affected by interactions with Greek financial assets, with income and expenditure decisions from non-Greek financial and economic interactions taken as given. As we assume a single homogenous good in the world economy, all trade balance effects are subsumed in the capital account.

The Greeks own a production technology (firms) requiring labour and capital as inputs. The production function of firms is denoted by $F\left(\operatorname{cap}_{t}^{G R C}, l a b_{t}^{G R C}\right)=$ $A_{t}\left(\operatorname{cap}_{t}^{G R C}\right)^{a}\left(l a b_{t}^{G R C}\right)^{1-a}$, a Cobb-Douglas production function, where $A_{t}$ is total factor productivity and $a$ and $1-a$ are the shares of output accruing to capital and household labour respectively. Greek households submit labour, $l a b_{t}^{G R C}$, to the labour market in return for a competitive wage $w_{t}$. Similarly, the capital stock, $\operatorname{cap}_{t}^{G R C}$, is rented from the capital market in exchange for a competitive rate of return. Greek households smooth intertemporally and finance their investments by issuing senior secured and junior unsecured debt, $b_{s, t}^{G R C}$ and $b_{u, t}^{G R C}$ respectively, from Germany at a competitive interest rate of 
$r_{t}^{s}$ and $r_{t}^{u}$. Unsecured debt is risky as Greeks may choose to renege a fraction $d e f_{t}^{G R C}$. If default occurs, Greeks incur a quadratic cost in renegotiating the remaining amount which depends on the prior scale of of debt. The proportionality factor, $\Omega_{t}^{G R C}$, scaling the cost of the default, is a macro-variable reflecting credit conditions. In addition, the lender can seize a proportion $\kappa$ of the outstanding amount from the income or capital stock of the borrower (this is the recovery rate). Greek households pay a cost when adjusting their secured debt positions, reflecting the costs associated with identifying suitable pledgeable assets, while German households pay a cost of adjusting their unsecured loans to Greeks, reflecting the costs of accumulating information on the probabilities of repayment. Throughout this paper we will use 'renegotiation rate' and 'default rate' interchangeably: they refer to the percentage of outstanding debt that Greeks would like to default upon, given the cost of renegotiating this amount. The 'repayment rate' is the percentage of outstanding debt which is repaid: it is $100 \%$ less the default rate plus the recovery rate.

The rate of time preference is $\beta$ and the coefficient of relative risk aversion is $\sigma$. Aggregate quantities are mostly denoted in uppercase, prices and aggregate rates have a superscript referring to the market (for wages and interest rates), but in some cases they do not have a superscript (for the aggregate repayment rate on debt); and finally (deterministic) steady state values have a bar.

There is one fundamental source of uncertainty in our economy: shocks to Greek Total Factor Productivity $(A)$. Fluctuations in TFP also determine various policy rules we consider for the recovery rate on outstanding debt: the recovery rate $(\kappa)$. We study the impact of TFP shocks only, because we believe that after the initial crisis episode in 2009, the economy continued 
to experience similar TFP shocks. Certainly it suffered many other shocks including, political (domestic and foreign, such as the refugee crisis) and global ones. Studying these and their implications for creditor debt policies would extend the analysis for beyond the more fundamental TFP shocks examined here. Finally, any other shocks that reduce the capital stock and/or national income directly can be summarised within the TFP shock which we model.

\subsection{Germany}

German households are assumed to have an outside source of income which does not depend on the loan portfolio extended to Greece, and reflects their total net foreign assets (NFA). In addition, they purchase one-period bonds issued by Greeks. Unsecured bonds are risky and there is an expected repayment rate associated with each bond. The net income from (ex-Greece) net foreign assets and bonds finances (marginal) consumption.

Preferences include a CRRA utility function for consumption.

$$
\max _{c, b_{s}, b_{u}} \sum_{s=0}^{\infty} \beta^{s} \mathbb{E}_{t}\left\{\frac{\left[c_{t+s}^{G E R}\right]^{1-\sigma}-1}{1-\sigma}\right\}
$$

Each period German households earn income, from their (ex Greece) net foreign assets and net Greek assets, and allocate it between consumption $\left(c_{t}^{G E R}\right)$ 
and new assets. Specifically ${ }^{13}$,

$$
\begin{aligned}
c_{t}^{G E R} & +b_{u, t}^{G E R}+b_{s, t}^{G E R}+\frac{a d j_{u}^{G E R}}{2}\left(b_{u, t}^{G E R}-\bar{b}_{u}^{G E R}\right)^{2}+N F A_{t}^{G E R} \\
& =\left(R_{t-1}^{u}\right)\left(1-d e f_{t}^{G R C}\right) b_{u, t-1}^{G E R}+\kappa_{t}\left(R_{t-1}^{u}\right)\left(d e f_{t}^{G R C}\right) b_{u, t-1}^{G E R} \\
& +\left(R_{t-1}^{s}\right) b_{s, t-1}^{G E R}+N F A_{t-1}^{G E R}\left(R_{t}^{N F A}\right) .
\end{aligned}
$$

The ex-Greece Net Foreign Asset position of German households is calibrated and assumed to evolve exogenously (a constant). The return on the NFA portfolio is also assumed to be exogenous and constant. ${ }^{14}$ Recall that $\kappa$ is the recovery rate on unsecured debt defaulted upon. It is exogenous to the model, but is interpreted as the outcome of a negotiation between creditors and debtors. $\kappa$ is also subject to shocks and follows the following process: $\kappa_{t}=\bar{\kappa} e^{\varepsilon_{t}^{\kappa}}$ where $\varepsilon_{t}^{\kappa}=\rho^{\kappa} \varepsilon_{t-1}^{\kappa}+u_{t}^{\kappa}$ is an autoregressive process subject to shocks $u_{t}^{\kappa}$.

The maximisation programme yields

$$
\begin{aligned}
& \psi_{t}^{G E R}=\left[c_{t}^{G E R}\right]^{-\sigma} \\
& \psi_{t}^{G E R}\left\{1+a d j_{u}^{G E R}\left(b_{u, t}^{G E R}-\bar{b}_{u}^{G E R}\right)\right\} \\
& =\beta^{G E R} \mathbb{E}_{t}\left\{R E P_{t+1} R_{t}^{u} \psi_{t+1}^{G E R}\right\} \\
& \psi_{t}^{G E R}=\beta^{G E R} \mathbb{E}_{t}\left\{R_{t}^{s} \psi_{t+1}^{G E R}\right\}
\end{aligned}
$$

\footnotetext{
${ }^{13}$ This quadratic adjustment term $\left(a d j j_{s}^{G E R}\right)$ is used to guarantee that secured debt holdings converge back to steady state values.

${ }^{14}$ One may think of this as the fruit of a non-stochastic Lucas tree. It is taken as a constant in order to isolate the marginal effect on German consumption of their Greek portfolio, independent of unrelated fluctuations in total German income. More importantly, we do not allow German lenders to have alternative opportunities to invest savings. However, the supply of loans is not elastic as Germans still have a legitimate consumption-savings decision, but the trade-off itself is limited to investments in Greece. Nevertheless, alternative investment opportunities would provide a richer framework to study the supply of loans to Greece.
} 
where $\psi_{t}^{G E R}$ is the marginal utility of consumption of German households and $R E P_{t+1}=1-\left(1-\kappa_{t+1}\right)\left(d e f_{t+1}^{G R C}\right)$ is the net delivery rate including the announced rate of default and the recovery rate. Note that German households care about the rate of return net-of-default and recovery. In the steady state, the net-of-default rate of return on loans is simply the rate of time preference.

Note that in the deterministic steady state $\frac{1}{\beta^{G E R}}=\bar{R}^{s}=\overline{R E P} \bar{R}^{u}$.

\subsection{Greece}

The Greek economy is represented by Greek households who wholly own firms in a competitive industry that identically has access to a production technology which uses capital $\left(c a p_{t}^{G R C}\right)$ and labour $\left(l a b_{t}^{G R C}\right)$ as inputs. The production function is Cobb-Douglas and has constant returns to scale, with an income share of $a$ and $1-a$ to capital and labour respectively

$$
F\left(c a p_{t-1}^{G R C}, l a b_{t}^{G R C}\right) \equiv A_{t}\left(c a p_{t-1}^{G R C}\right)^{a}\left(l a b_{t}^{G R C}\right)^{1-a} .
$$

Capital depreciates at a rate of $\delta \%$ each period and labour is paid a competitive wage $w_{t}^{N} . A_{t}=e^{\varepsilon_{t}^{A}} A$ is the total factor productivity and $\varepsilon_{t}^{A}=\rho^{A} \varepsilon_{t-1}^{A}+u_{t}^{A}$ is an autoregressive process with shock $u_{t}^{A}$. As there is a representative firm, National Production or GDP, is defined as $Y_{t}=F\left(\operatorname{cap}_{t-1}^{G R C}, l a b_{t}^{G R C}\right)$. Profits of Greek firms are

$$
\pi_{t}^{G R C} \equiv F\left(c a p_{t-1}^{G R C}, l a b_{t}^{G R C}\right)+(1-\delta) c a p_{t-1}^{G R C}-w_{t}^{N} l a b_{t}^{G R C}-R_{t}^{k} c a p_{t-1}^{G R C}
$$


Firms maximise profits each period which results in factor prices being determined at their marginal product values

$$
\begin{aligned}
w_{t}^{N} & =\frac{\partial F\left(c a p_{t-1}^{G R C}, l a b_{t}^{G R C}\right)}{\partial l a b_{t}^{G R C}}, \\
R_{t}^{k} & =\frac{\partial F\left(c a p_{t-1}^{G R C}, l a b_{t}^{G R C}\right)}{\partial c a p_{t-1}^{G R C}}+1-\delta .
\end{aligned}
$$

Greek households access the international debt market and issue secured $\left(b_{s}^{G R C}\right)$ and unsecured $\left(b_{u}^{G R C}\right)$ claims at competitive interest rates $\left(R^{s}\right.$ and $R^{u}$ are the gross rates, respectively) in order to finance consumption and investment decisions. Crucially, they decide how much of their debt obligation to repay.

If they do not honour their unsecured debt completely, they incur a nonpecuniary punishment, or utility cost, proportional to the amount they default upon, which reflects the costs involved in renegotiating the outstanding amount. Furthermore, lenders are able to seize a fraction $(\kappa)$ of the outstanding debt from the new capital stock. We will conduct our normative policy analysis on four different descriptions of the path of the recovery rate, $\kappa$. These policies reflect the severity of imposed austerity policies that increase the net repayment to creditors. In Section 4 we detail this fully.

Secured debt is lent up to the present value of the future remaining stock ${ }^{15}$. Specifically, the amount due on secured debt must be backed by at least

\footnotetext{
${ }^{15}$ This can be thought of as a collateral constraint where failure to honour secured debt obligations results in seizure of collateral, as in Kiyotaki and Moore (1997) and Geanakoplos and Zame (2014) among others. However, as there is no stochastic component in the constraint no possibility for default exists it is interpreted as a limit on the available secured debt.
} 
$\operatorname{coll}^{G R C} \%$ of the remaining capital stock when it is due,

$$
b_{s, t-1}^{G R C}\left(R_{t-1}^{s}\right) \leq \operatorname{coll}^{G R C} \operatorname{cap}_{t-1}^{G R C}(1-\delta) .
$$

The budget constraint of the Greek household requires the allocation of income from profits and labour plus new borrowings to consumption, investment, and repayment of existing debt as follows

$$
\begin{aligned}
c_{t}^{G R C} & +c a p_{t}^{G R C}+\left(R_{t-1}^{s}\right) b_{s, t-1}^{G R C}+\left(1-d e f_{t}^{G R C}\right)\left(R_{t-1}^{u}\right) b_{u, t-1}^{G R C} \\
= & \pi_{t}^{G R C}+R_{t}^{k} c a p_{t-1}^{G R C}+w_{t}^{N} l a b_{t}^{G R C}+b_{s, t}^{G R C}+b_{u, t}^{G R C} \\
& -\frac{a d j_{s}^{G R C}}{2}\left(b_{s, t}^{G R C}-\bar{b}_{s}^{G R C}\right)^{2}-\kappa_{t} d e f_{t}^{G R C}\left(R_{t-1}^{u}\right) b_{u, t-1}^{G R C}
\end{aligned}
$$

where $c^{G R C}$ is consumption, unsecured and secured debt issued is $b_{u}^{G R C}$ and $b_{s}^{G R C}$ respectively, at a gross interest rate of $\left(R^{u}\right)$ and $\left(R^{s}\right)$ respectively, and the proportion of unsecured outstanding debt repaid is $\left(1-d e f^{G R C}\right) \cdot \kappa_{t} d e f_{t}^{G R C}\left(R_{t-1}^{u}\right) b_{u, t-1}^{G R C}$ is the amount lenders seize from the new capital stock, and $\frac{a d j_{u}^{G R C}}{2}\left(b_{u, t}^{G R C}-\bar{b}_{u}^{G R C}\right)^{2}$ is the cost of adjusting unsecured debt away from steady state levels and can be interpreted as the cost of renegotiating a different level of unsecured debt. We allow the capital stock to be substitutable with income, and as a consequence there is no non-negativity constraint on re-investment. The preferences include a CRRA utility function for consumption and disutilities from supplying labour and from renegotiating defaulted upon debt. The decision variables 
are $c, l a b, b_{s}, b_{u}, \operatorname{def}, c a p$.

$$
W_{t}^{G R C}=\left[\frac{\left(c_{t}^{G R C}\right)^{1-\sigma}-1}{1-\sigma}-\frac{\eta}{2}\left(l a b_{t}^{G R C}\right)^{2}-\frac{1}{2}\left\{d e f_{t}^{G R C}\left(R_{t-1}^{u}\right) b_{u, t-1}^{G R C}\right\}^{2} \Omega_{t}^{G R C}\right] .
$$

and permits the usual recursive representation. The recursive representation of preferences is

$$
W_{t}^{G R C}=\sum_{s=0}^{\infty} \beta^{s} \mathbb{E}_{t} W_{t+s}^{G R C}
$$

The (non-pecuniary) renegotiation cost households must pay if they choose to default on $d e f_{t}^{G R C} \%$ of their unsecured debt is

$$
\frac{1}{2}\left\{\zeta+d e f_{t+s}^{G R C}\left(R_{t+s-1}^{u}\right) b_{u, t+s-1}^{G R C}\right\}^{2} \Omega_{t+s}^{G R C},
$$

where $\Omega_{t}^{G R C}$ is a pro-cyclical macro-variable which governs the severity of the punishment enforced and $\zeta \rightarrow 0$ is an infinitesimally small positive number ${ }^{16}$. $\Omega_{t}^{G R C}$ is given by

$\Omega_{t}^{G R C} \equiv \phi^{G R C}\left\{\frac{(1-\bar{\kappa}) \bar{\psi}^{G R C}\left(1-\overline{d e f}^{G R C}\right)\left(\overline{\operatorname{def}}^{G R C}\right)^{\gamma-1}}{\overline{C A P}^{G R C}}\right\} \frac{C A P_{t-1}^{G R C}}{B_{u, t-1}^{G R C}\left(1+r_{t-1}^{u}\right)\left(d e f_{t}^{G R C}\right)^{\gamma}}$.

$\Omega_{t}^{G R C}$ is the shadow cost of renegotiation, or the stochastic discount factor for the cost of renegotiating debt in arrears. $\bar{\psi}^{G R C}$ is the steady state shadow value of consumption for the Greek household. $\phi^{G R C}$ is what we call the default wedge and determines the steady state rate of default. The aggregate default

\footnotetext{
${ }^{16}$ This parameter allows two steady-state equilibria to be supported; one where there is no default and one where default occurs in equilibrium. For the remainder of this section we consider the limit of $\zeta=0$ but return to it in Section 3.1.
} 
rate also appears in the denominator as it allows us to consider the marginal effect of the decision of an individual firm on the aggregate cost of default to the whole economy. The inverse of the leverage ratio in the previous period also enters as the ratio of the aggregate capital stock to the aggregate debt due. As a consequence, $\Omega_{t}^{G R C}$ turns out to be pro-cyclical, i.e. with a high cost (high value) in good times and a low cost (low value) in depressions. To see this, note that when the capital stock is growing the ratio of debt to physical capital stock as debt is growing, and so the shadow value of default $\Omega_{t}^{G R C}$ is low. When the shadow cost of default is low, the firms default rate is likely to be higher (all else being equal). ${ }^{17}$

$\Omega_{t}^{G R C}$ dynamically governs the cost of default. In Dubey et al. (2005) this is a constant, but the marginal cost of default is only proportional to this and hence constant. Here, even if $\Omega_{t}^{G R C}$ was constant, the marginal cost of default, here renegotiation, is proportional to the quantity in arrears. This alone would allow us to obtain a stationary solution. In contrast, Walsh (2015a) and Walsh (2015b) have $\Omega_{t}^{G R C}$ to be a function of household wealth. As this is dynamic, so is $\Omega_{t}^{G R C}$. However, there, this is necessary in order to obtain a stationary solution as the marginal cost of default is still linear in $\Omega_{t}^{G R C}$. This is not so in our case. We obtain stationarity by having the marginal cost proportional to the quantity of default, however this alone would mean that the propensity to default decreases as the quantity of debt outstanding increases. The specification we have chosen for $\Omega_{t}^{G R C}$ negates this, as it falls when default rates

\footnotetext{
${ }^{17}$ In richer models, where there are heterogenous productive sectors, default in one sector will cause default in others: the chain reaction of default can exacerbate the financial difficulties of a relatively small sector of the economy into an economy-wide contagion. Our macroeconomic variable, $\Omega$ captures this notion that industries are linked and default is amplified as it spreads. An analogy is that if one room of a house floods, the entire house is likely to be flooded.
} 
and the stock of debt grows, hence increasing the propensity to default when the stock of debt grows, addressing the empirical findings in the literature ${ }^{18}$.

The optimisation yields the following first order conditions, with $\psi_{t}^{G R C}$ defined as the shadow value of income and $\lambda_{t}^{G R C}$ is the Lagrange multiplier for the limit of issuing secured debt at $t-1$, and interpreted as the shadow value of secured debt:

$$
\begin{aligned}
& \eta l a b_{t}^{G R C}=\psi_{t}^{G R C} w_{t} \\
& \psi_{t}^{G R C}-\operatorname{coll}^{G R C}(1-\delta) \lambda_{t}^{G R C}=\mathbb{E}_{t} \beta\left\{\psi_{t+1}^{G R C}\left(R_{t+1}^{k}\right)\right\} \\
& \frac{\psi_{t}^{G R C}}{R_{t}^{u}}= \\
& \mathbb{E}_{t} \beta\left\{\left(1-\left(1-\kappa_{t+1}\right) d e f_{t+1}^{G R C}\right) \psi_{t+1}^{G R C}+\left(\operatorname{def} f_{t+1}^{G R C}\right)^{2}\left(R_{t}^{u}\right) b_{u, t}^{G R C} \Omega_{t+1}^{G R C}\right\} \\
& \psi_{t}^{G R C} b_{u, t-1}^{G R C}\left(R_{t-1}^{u}\right) \\
& \quad=d e f_{t}^{G R C}\left(R_{t-1}^{u}\right)^{2}\left(b_{u, t-1}^{G R C}\right)^{2} \Omega_{t}^{G R C}+\kappa_{t}\left(R_{t-1}^{u}\right) b_{u, t-1}^{G R C} \psi_{t}^{G R C} \\
& \frac{\psi_{t}^{G R C}}{R_{t}^{s}}\left(1-a d j_{s}^{G R C}\left(b_{s, t}^{G R C}-\bar{b}_{s}^{G R C}\right)\right)-\lambda_{t}^{G R C}=\mathbb{E}_{t} \beta\left\{\psi_{t+1}^{G R C}\right\}
\end{aligned}
$$

Equation 16 is the FOC wrt to labour supplied while 17 is the FOC wrt capital and states that the shadow value of capital equals the marginal effect of capital on profits plus the increase in future capital stock. 18 is the FOC with respect to unsecured debt and states that the marginal benefit of debt in increasing the shadow value of capital is equated to the marginal cost of reducing profits by the repayment rate and the renegotiation cost of increasing the quantity of debt subject to default. Equation 19 is the FOC with respect to the repayment rate on loans and equalises the marginal cost on profits of repaying an additional

\footnotetext{
${ }^{18}$ As in Benjamin and Wright (2013)
} 
percent of debt to the marginal benefit of reducing the renegotiation cost of defaulting. Equation 20 is the FOC with respect to the secured debt issued.

The first order conditions give:

$$
\phi^{G R C}\left\{\frac{d e f_{t}}{\overline{d e f}}\right\}^{1-\gamma}=\frac{1}{1-\overline{d e f}^{G R C}} \frac{\lambda_{t}^{G R C}}{\bar{\lambda}^{G R C}},
$$

and in the deterministic steady state

$$
\frac{1}{\beta^{G R C}}=\bar{R}^{u},
$$

and hence

$$
1-\overline{d e f}^{G R C}=\frac{1}{\phi^{G R C}}=\frac{\beta^{G R C}}{\beta^{G E R}} .
$$

These results will be explained in Section 3.

\subsubsection{Interpretation of Parameters}

The Greek economy that we model is a decentralised economy but we interpret the economy to be the outcome of national economic interactions. In other words, we subsume the activities (and consequences) of government behaviour into the budget constraints of the representative household. The stock of unsecured and secured debt reflects the total national external liabilities. The default variable $d e f_{t}$ is interpreted as the proportion of national external debt that the sovereign would, ideally, like to default upon. $1-R E P_{t}$ is the final amount that the country is allowed to default upon after negotiation. This is the final (quarterly) haircut on the stock of debt afforded to Greece. The

collateral parameter $\mathrm{coll}^{G R C}$ reflects the constraints on the lender to issue 
subsidised loans at the risk-free rate, which may arise from legal restrictions or restrictions imposed by internal credit risk models, and possibly the creditors. The unsecured interest rate is the average interest rate that Greek borrowers face, implicitly implying that the private sector can borrow at the same rate as the government. In the calibration of the model, the difficulties in combining private and public sector liabilities into a representative household has required us to use source data from the private sector but which are consistent with observed public sector and national variables.

\section{Default and the Business Cycle}

\subsection{Multiple Equilibria}

Assume there exists a steady state where default rates are zero. Such a steadystate can be supported when default penalties are exceedingly harsh. If agents do not default, it is because the marginal cost of defaulting is strictly greater than the marginal benefit of defaulting. Alternatively, if the marginal benefit and cost of defaulting are equated, then default obtains in the steady state. In particular, the marginal benefit of defaulting is the marginal increase in wealth from reducing repayments whereas the marginal cost of defaulting is the increase in the renegotiation cost. In our model, when the two are equated, then Equation 19 holds with equality. Note that the limit of $\zeta=0$ was set in Equation 19. Then, let us postulate the existence of a steady-state where default does not occur and $\zeta>0$. The marginal benefit of default is the left

hand side of Equation 19, $\psi_{t}^{G R C} b_{u, t-1}^{G R C}\left(R_{t-1}^{u}\right)$, while the marginal cost of defaulting is the right hand side, $\left(R_{t-1}^{u}\right)\left(b_{u, t-1}^{G R C}\right)\left(\zeta+d e f_{t}^{G R C}\left(R_{t-1}^{u}\right)\left(b_{u, t-1}^{G R C}\right)\right) \Omega_{t}^{G R C}+$ 
$\kappa_{u}^{G R C}\left(R_{t-1}^{u}\right) b_{u, t-1}^{G R C} \psi_{t}^{G R C}$ in the assumed steady-state. Since $d e f_{t}^{G R C}=0$, the marginal cost of defaulting becomes $\left(R_{t-1}^{u}\right)\left(b_{u, t-1}^{G R C}\right) \zeta \Omega_{t}^{G R C}+\kappa_{u}^{G R C}\left(R_{t-1}^{u}\right) b_{u, t-1}^{G R C} \psi_{t}^{G R C}$. Hence, $\Omega_{t}^{G R C}=\frac{\phi^{G R C}(1-\bar{\kappa}) \bar{\psi}^{G R C}}{B_{u, t-1}^{G R C}\left(1+r_{t-1}^{u}\right)\left(d e f_{t}^{G R C}\right)}=\infty$. In conclusion, when $\zeta>0$, the marginal cost of default becomes infinite, and therefore there is no default. ${ }^{19}$ In this default-free equilibrium, Greek households borrow freely at a risk-free interest rate. However, if creditor's expectations become pessimistic, credit spreads will increase, resulting in default. Nevertheless, a credible and transparent business plan may improve creditors' expectations, thus eliminating default.

As our interest is the post-crisis era, we now continue our analysis on the steady-state with default and renegotiation.

\subsection{Default Wedge}

We term $\phi^{G R C}$ the default wedge. $\phi^{G R C}$ is the mark-up of the return from capital over the net pecuniary interest cost of debt (after accounting for default). It is a measure of the renegotiation cost of default. In the absence of default, the expected return to capital will equate the return to debt, and hence $\phi^{G R C}=1 . \phi^{G R C}>1$ implies a higher unsecured interest rate (and hence return on capital), or a lower capital stock and so is the effective tightness of credit conditions because of expectations of default. The reason that the rate of repayment affects steady-state allocations arises from the asymmetry of the way default is modelled here. In the steady state, the lender equates the net-of-default return on debt to their rate of time preference. Thus, a lower

\footnotetext{
${ }^{19}$ We could have avoided using limits for the argument, however this would have required a more cumbursome calibration of values to sustain both steady-states.
} 
repayment rate, or higher default rate, increases the gross interest rate they demand, which, in turn, increases the return on capital and lowers the steady state capital stock.

\subsection{Default Accelerator}

$\gamma$ is the default accelerator as it governs the amplification of default through the credit conditions variable. For $\gamma<1$, a negative shock to income raises the marginal utility of income $\lambda_{t}^{G R C}$ which then increases the individual propensity

to default $d e f_{t}^{G R C}$, which then is reflected in the aggregate interest rate, and so in turn again increases the individual propensity to default. As a consequence, $\gamma$ allows us to calibrate the volatility of default rates independently of the equilibrium average default rate, which is determined by $\phi^{G R C}$.

\subsection{Default Premium and Endogenous Liability Struc- ture}

If secured debt did not need not be collateralised, $\bar{R}^{k}=\bar{R}^{u}>\bar{R}^{s}$. In other words, the return on capital would be equated to the unsecured bond interest rate which would be strictly higher than the secured (but uncollateralised) bond interest rate. Here, where secured debt must be collateralised by capital we obtain the following relationship

$$
\bar{R}^{u}=\frac{\bar{R}^{k}-\operatorname{coll}(1-\delta)}{\bar{R}^{s}-\operatorname{coll}(1-\delta)} \bar{R}_{s}
$$


which is simply

$$
1-\overline{d e f}=\frac{1}{\phi^{G R C}}=\frac{\bar{R}^{s}-\operatorname{coll}(1-\delta)}{\bar{R}^{k}-\operatorname{coll}(1-\delta)}
$$

where $\frac{\bar{R}^{k}-\operatorname{coll}(1-\delta)}{\bar{R}^{s}-\operatorname{coll}(1-\delta)}$ is the default premium. An increase in the default wedge $(\phi)$ increases default rates $(\overline{d e f})$ which increases the spread of the return to capital over the secured interest rate $\left(\frac{\bar{R}^{k}}{\bar{R}^{s}}\right)$, increasing the required return on capital and and lowering the capital stock $(\overline{C A P}$. $)$ Because of the need for collateral, a fall in the capital stock, leads to a fall in the stock of secured debt issued by the Greek households $\left(\bar{b}_{s}^{G R C}\right)$ and the ratio of secured to unsecured debt $\left(\frac{b_{t, s}^{G R C}}{b_{t, u}^{G R C}}\right)$. In other words, over the business cycle the composition of liabilities issued by Greek households fluctuates via the default channel.

\section{1st Order Approximation Policy Experiment}

In this section we perform analysis of the model using a 1st order linear approximation. The repayment policies we consider refer to the recovery rate. The recovery rate $\left(\kappa_{t}\right)$ is the proportion of debt that Greece would like to default upon, which creditors do not agree to and hence recover. In principle this process can take any form but we focus on policies which respond to fundamentals (TFP specifically).

We model the process as $\kappa_{t}=\bar{\kappa} e^{\varepsilon_{t}^{\kappa}}$ where $\varepsilon_{t}^{\kappa}=\rho^{\kappa} \varepsilon_{t-1}^{A}+u_{t}^{\kappa}$ where $\varepsilon_{t-1}^{A}$ is the previous period's TFP deviation. The policy regimes we consider correspond to modelling the coefficient and shock:

- Acyclical (Acyc): $\rho^{k}=u_{t}^{\kappa}=0$ 
- Harsh/Procyclical (Pro): $\rho^{k}=-.2 \rho^{A}, u_{t}^{\kappa}=-10 u_{t}^{A}$

- Lenient/Countercyclical (Countc): $\rho^{k}=.2 \rho^{A}, u_{t}^{\kappa}=10 u_{t}^{A}$

Under the Acyclical policy, the recovery rate remains at the steady state value. Under the Procyclical policy, a negative TFP shock generates an immediate increase in the recovery rate and the recovery rate remains above steady state levels as long as TFP is below its steady state level. The Countercyclical policy has the opposite description.

\subsection{Calibration}

We have calibrated our economy according to the values provided in previous studies at a quarterly frequency. First we discuss the calibration with respect to the Acyclical recovery rate policy. The secured interest rate is $2 \%$ per annum while the unsecured rate is $12.9 \%$ per annum. This compares with the average Germany 10 year yield from January 2010 to October 2014 of 1.916\% and Greek 10 year bond yield from January 2010 to January 2015 of $12.81 \% .{ }^{20}$ The recovery rate on Greek debt was taken from Vrugt (2011) who estimated that the recovery rate on Greek debt to be between 40 and 60 - we have taken the midpoint of 50. This is also the number documented in the cross-country findings of recovery rates found in Benjamin and Wright (2013). The volatility of default rates was taken from the Standard and Poors Ratings Direct study "Default, Transition, and Recovery: 2012 Annual Global Corporate Default Study And Rating Transitions", which gave the mean and standard deviation of annual European Corporate Speculative-Grade Default

\footnotetext{
${ }^{20}$ Taken from St Louis FRED database "Long-Term Government Bond Yields: 10-year: Main (Including Benchmark)".
} 
Rates as $3.1 \%$ and $3.46 \%$ respectively. The mean and standard deviation of default rates is $5 \%$ and $15.9 \%$, which, after renegotiation (which includes a recovery rate of 50\%), corresponds to debt repayment rates with mean and standard deviation of $97.5 \%$ and $7.95 \%$ respectively. The present value of the debt forgiven is around $17.5 \%$, using the model unsecured interest rate. These were set by choosing the default wedge, $\phi$, to be $1 / .95$ and the default accelerator, $\gamma$, to be .93 to obtain higher volatility in default decisions and obtain counter-cyclical effects of default. The standard deviation of the shock $\left(u_{A}\right)$ is $.212 \%$, and the coefficient of relative risk aversion, $\sigma$, is 2 , following Angelopoulos et al. (2010). In the same paper, the private depreciation rate of capital was $1.75 \%$ per quarter. We have chosen a slightly higher rate of $2.5 \%$ to increase investment and compensate for the static capital stock due to a lack of growth in our model. Angelopoulos et al. (2010) have a labour share of income of .66 , so we choose $a$ to be .34 . The labour supply is set to .3544 which is the average value of hours of work in Angelopoulos et al. (2010). The ratio of unsecured to secured debt in our economy is .5. The ratio of short to long term public debt in Greece reported in Karmann and Maltritz (2012) is .25 , and we have used this to obtain a rough estimate of the ratio of secured to unsecured debt, assuming that short-term debt needs to be renegotiated more immediately. Eurostat gives the net external debt to GDP ratio of Greece to be $130 \%$ in 2013 . We directly set the steady-state values of debt to obtain this figure in our calibration. World Bank figures for the Net Foreign Asset (NFA) positions of Greece and Germany gives a ratio of almost 30 in 2010 and almost 60 in 2013 which we use to obtain the ex-Greece NFA for Germany of 30 times Greek total debt. Table 1 lists values and sources. 


\begin{tabular}{ccccc}
\hline Parameter & Description & Model Value & Source Value & Reference \\
\hline \hline$u_{A}$ & Standard Deviation of TFP Shock & $.212 \%$ & $.212 \%$ & Angelopoulos et al. (2010) \\
$\rho_{A}$ & Persistence of TFP shock & .675 & .675 & Angelopoulos et al. (2010) \\
$\sigma$ & Coefficient of relative risk aversion & 2 & 2 & Angelopoulos et al. (2010) \\
$\delta$ & Depreciation rate & $2.5 \%$ & $1.75 \%$ & Angelopoulos et al. (2010) \\
$a$ & Share of Capital Income in Greece & .34 & .34 & Angelopoulos et al. (2010) \\
$l a b$ & Steady-state labour supply & .353 & .353 & Angelopoulos et al. (2010) \\
$b_{u} / b_{s}$ & Unsecured-to-Secured Debt & .5 & .25 & Karmann and Maltritz (2012) \\
$\left(b_{s}+b_{u}\right) / Y_{R C}$ & Greek Debt-to-GDP & $130 \%$ & $130 \%$ & Eurostat \\
$N F A /\left(b_{s}+b_{u}\right)$ & Ex-Greece, German Net Foreign Assets & 30 & 29 to 60 & World Bank \\
$E\left(R_{t}^{s}-1\right)$ & Mean Annual Secured interest rate & $2 \%$ & $1.916 \%$ & St. Louis/FRED \\
$E\left(R_{t}^{u}-1\right)$ & Mean Annual Unsecured interest rate & $12.9 \%$ & $12.81 \%$ & St.Louis FRED \\
$E($ def $)$ & Mean default rates & $5 \%$ & $3.1 \%$ & S\&P \\
$S t D($ def $)$ & Variance of default rates & $15.9 \%$ & $3.46 \%$ & S\&P \\
$\kappa$ & Recovery rate on unsecured debt & 0.5 & 0.5 & Vrugt (2011) \\
\hline \hline
\end{tabular}

Table 1: List of Calibrated Values

Table 2 below shows the parameterisation of the economy.

\begin{tabular}{ccc}
\hline Parameter & Description & \\
\hline \hline$\beta^{G E R}$ & German rate of time preference & 0.995 \\
$\beta^{G R C}$ & Greek rate of time preference & 0.970 \\
$\phi^{G R C}$ & default wedge & $1 / .950$ \\
$\gamma$ & default accelerator & .930 \\
$A_{t}$ & total factor productivity & 1.052 \\
$\eta$ & household preference for labour & 7.656 \\
coll & collateral requirement & .1375 \\
\hline \hline
\end{tabular}

Table 2: List of Parameters

\subsection{Business Cycle Properties}

In this section ${ }^{21}$ we first simulate the 1st order approximate version of the economy and study the business cycle properties of our economy. We then examine the impulse responses of our policy regimes.

\footnotetext{
${ }^{21}$ Numerical calulations were performed in Dynare. We consider deviations from the level.
} 


\subsection{Simulated Economy}

Table 3 shows the moments of key variables in our economy. The mean values change little across the policy regimes. However the standard deviation of all the variables apart from the repayment rate is lowest under a Countercyclical policy. Capital, labour, and debt are strongly pro-cyclical while consumption becomes less cyclical reflecting large capital outflows and economic contraction in times of crisis. Although the secured interest rate is procyclical, the unsecured rate is strongly countercyclical reflecting the procyclical repayment rate. In other words default occurs in bad times and is consistent with the empirical literature and arguments of Arellano (2008) and Aguiar and Gopinath (2006). Under a Countercyclical policy, repayment rates are the least persistent due to the way the policy offsets the transmission effects of default. 


\begin{tabular}{|c|c|c|c|c|c|c|}
\hline & \multicolumn{3}{|c|}{ Mean } & \multicolumn{3}{|c|}{ Standard Deviation } \\
\hline & Acyc & Pro & Countc & Acyc & Pro & Countc \\
\hline$R_{t}^{s}-1$ & 0.0050 & 0.0050 & 0.0050 & 0.0431 & 0.0491 & 0.0371 \\
\hline$R_{t}^{u}-1$ & 0.0308 & 0.0308 & 0.0308 & 0.0121 & 0.0141 & 0.0102 \\
\hline$R E P$ & 0.9750 & 0.9750 & 0.9750 & 0.0795 & 0.1088 & 0.1153 \\
\hline$R^{k}-1$ & 0.0273 & 0.0273 & 0.0273 & 0.0050 & 0.0058 & 0.0042 \\
\hline $\operatorname{cap}^{G R C}$ & 6.4970 & 6.4970 & 6.4970 & 1.1090 & 1.2591 & 0.9595 \\
\hline wage $e^{G R C}$ & 1.8681 & 1.8681 & 1.8681 & 0.1308 & 0.1465 & 0.1151 \\
\hline$l a b^{G R C}$ & 0.3533 & 0.3533 & 0.3533 & 0.0238 & 0.0282 & 0.0195 \\
\hline$Y^{G R C}$ & 1.0000 & 1.0000 & 1.0000 & 0.0872 & 0.0971 & 0.0782 \\
\hline$c^{G E R}$ & 0.8311 & 0.8311 & 0.8311 & 0.0441 & 0.0520 & 0.0362 \\
\hline$c^{G R C}$ & 1.1765 & 1.1765 & 1.1765 & 0.1754 & 0.2039 & 0.1473 \\
\hline$b_{s}$ & 0.8667 & 0.8667 & 0.8667 & 0.1264 & 0.1432 & 0.1097 \\
\hline \multirow[t]{3}{*}{$b_{u}$} & 0.4333 & 0.4333 & 0.4333 & 2.2930 & 2.5883 & 2.0007 \\
\hline & \multicolumn{3}{|c|}{ Correlation with } & \multicolumn{3}{|c|}{ First Order } \\
\hline & Acyc & Pro & Countc & Acyc & Pro & Countc \\
\hline$R_{t}^{s}-1$ & 0.3830 & 0.3234 & 0.4549 & 0.9381 & 0.9442 & 0.9296 \\
\hline$R_{t}^{u}-1$ & -0.5845 & -0.5324 & -0.6425 & 0.9749 & 0.9748 & 0.9751 \\
\hline$R E P$ & 0.7328 & 0.5262 & 0.5887 & 0.9792 & 0.5469 & 0.4475 \\
\hline$R^{k}-1$ & -0.7556 & -0.7402 & -0.7465 & 0.9740 & 0.9828 & 0.9570 \\
\hline $\operatorname{cap}^{G R C}$ & 0.9135 & 0.8980 & 0.9256 & 0.9950 & 0.9952 & 0.9946 \\
\hline wage $e^{G R C}$ & 0.6530 & 0.6034 & 0.7108 & 0.9238 & 0.9304 & 0.9150 \\
\hline$l a b^{G R C}$ & 0.6165 & 0.6227 & 0.6214 & 0.9639 & 0.9551 & 0.9752 \\
\hline$Y^{G R C}$ & 1.0000 & 1.0000 & 1.0000 & 0.9892 & 0.9941 & 0.9793 \\
\hline$c^{G E R}$ & 0.0395 & -0.0196 & 0.1081 & 0.9119 & 0.9121 & 0.9118 \\
\hline$c^{G R C}$ & 0.4521 & 0.4958 & 0.4003 & 0.9110 & 0.9108 & 0.9118 \\
\hline$b_{s}$ & 0.9563 & 0.9574 & 0.9471 & 0.9942 & 0.9945 & 0.9937 \\
\hline$b_{u}$ & 0.9547 & 0.9484 & 0.9581 & 0.9963 & 0.9964 & 0.9958 \\
\hline
\end{tabular}

Table 3: Business Cycle Properties of Simulated Economy 


\subsection{Impulse Responses}

Figures 2 to 4 give the impulse responses following a negative TFP shock. When it occurs, the reduction in income (before an adjustment in labour supply) increases the marginal cost of honouring debt and default rates rise. As default rates rise the credit conditions variable worsens and through the default accelerator we see an immediate large increase in default rates. There is also a contraction in investment (seen in a lower capital stock, debt and higher German consumption or less German saving), which through the worsening expected credit conditions and default accelerator, raises future default rates. The higher default premium then raises the cost of debt, and the required return on capital, causing a further cycle of capital stock contraction.

The immediate reduction in income from lower TFP reduces wages, increasing labour supply and ultimately offsetting lower TFP to increase output. The higher cost of issuing debt results in a deleveraging in the Greek economy and investment is increasingly financed through domestic savings resulting in a decline in Greek consumption.

In the following quarters, lower TFP lowers the return on investment, driving down the issuance of debt issued by Greeks partly offset by internal financing, and so Greek consumption remains below steady state values. Default rates above steady state values increase the required rate of return on unsecured debt and consequently return on capital. The large increase in the unsecured interest rate then corresponds to a large decrease in the capital stock and production. The liability structure of the Greek economy also substitutes away from unsecured borrowing to internal financing and the ratio of unsecured to secured debt continues to fall. While the required return on un- 
secured debt increases, the required return on secured debt falls. Default rates and the economy overall begin to converge back to steady state values after 20-30 quarters when the credit conditions macro-variable begins to converge back to steady state values.

From the lender's (German) point of view, the lower requirement for external financing of the capital stock, increases German net income and consumption initially, but, as the need for external financing subsequently increases, German consumption starts to fall below steady state values. The economy is close to steady state values after 60 quarters.

\section{Policy Regimes}

The Procyclical policy regime (red starred series) has much larger fluctuations than the other ones, driven by the larger immediate decline in Greek capital and consumption as a result of higher repayment requirements. In contrast, the Countercyclical policy (green square series) insulate the Greek economy at the cost of an immediate fall in German Consumption. The Countercyclical policy lowers the recovery rate following a TFP shock, resulting in higher immediate default rates and unsecured interest rate. This translates into a faster downward adjustment in the capital stock but also faster recovery from 20 quarters onwards. Overall, the Countercyclical recovery rate policy results in smaller fluctuations and faster convergence to the steady state. The difference between the policy regimes is affected by the relatively small size of the policy adjustment modelled. Policy adjustments can be scaled to amplify the differences between the series. The results above are from a model of private borrowing and default. However, that the propensity for default depends on 

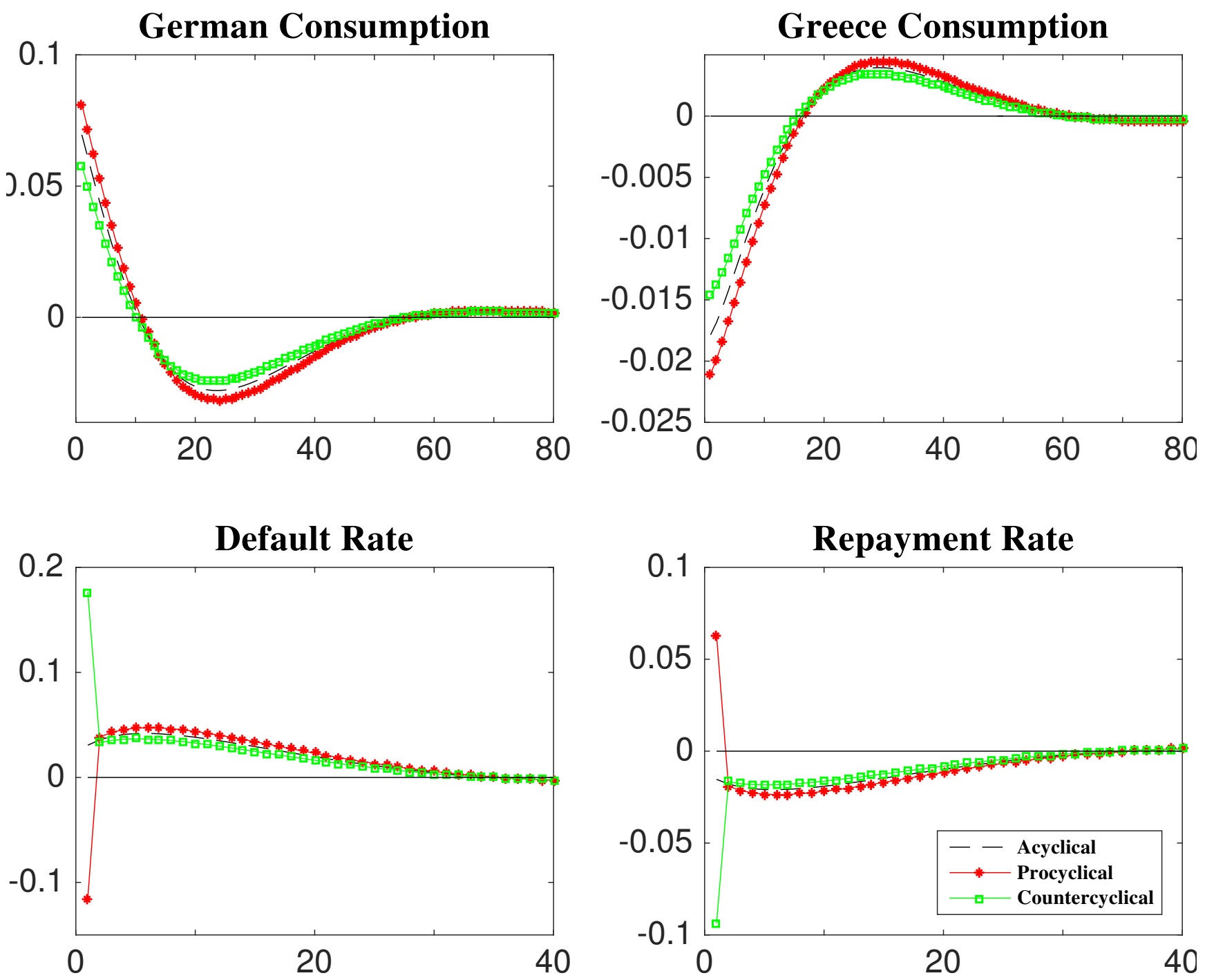

Figure 2: Average stochastic path following negative TFP shock under different policy regimes. Welfare is the conditional welfare series. 

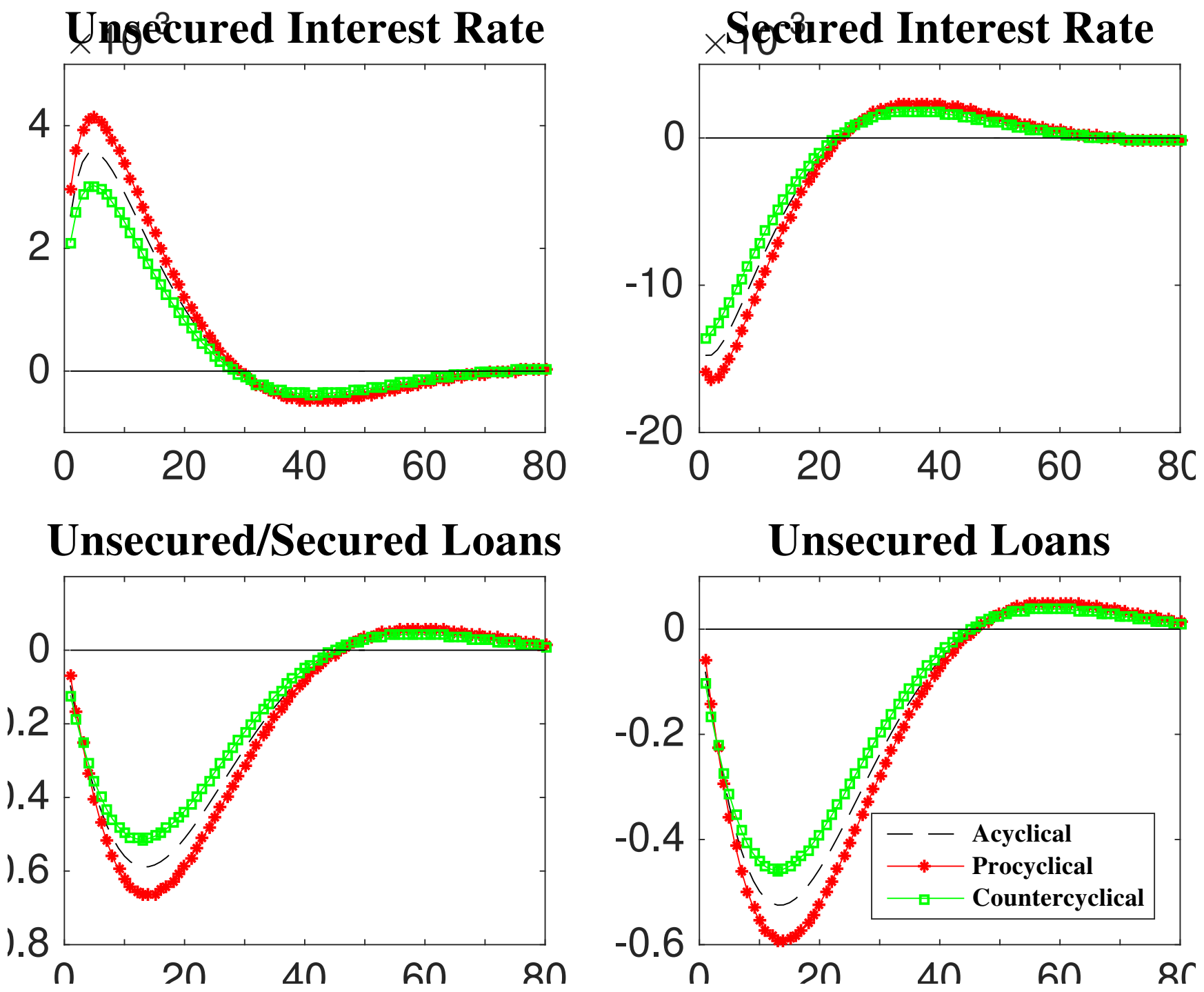

Figure 3: Average stochastic path following negative TFP shock under different policy regimes. 

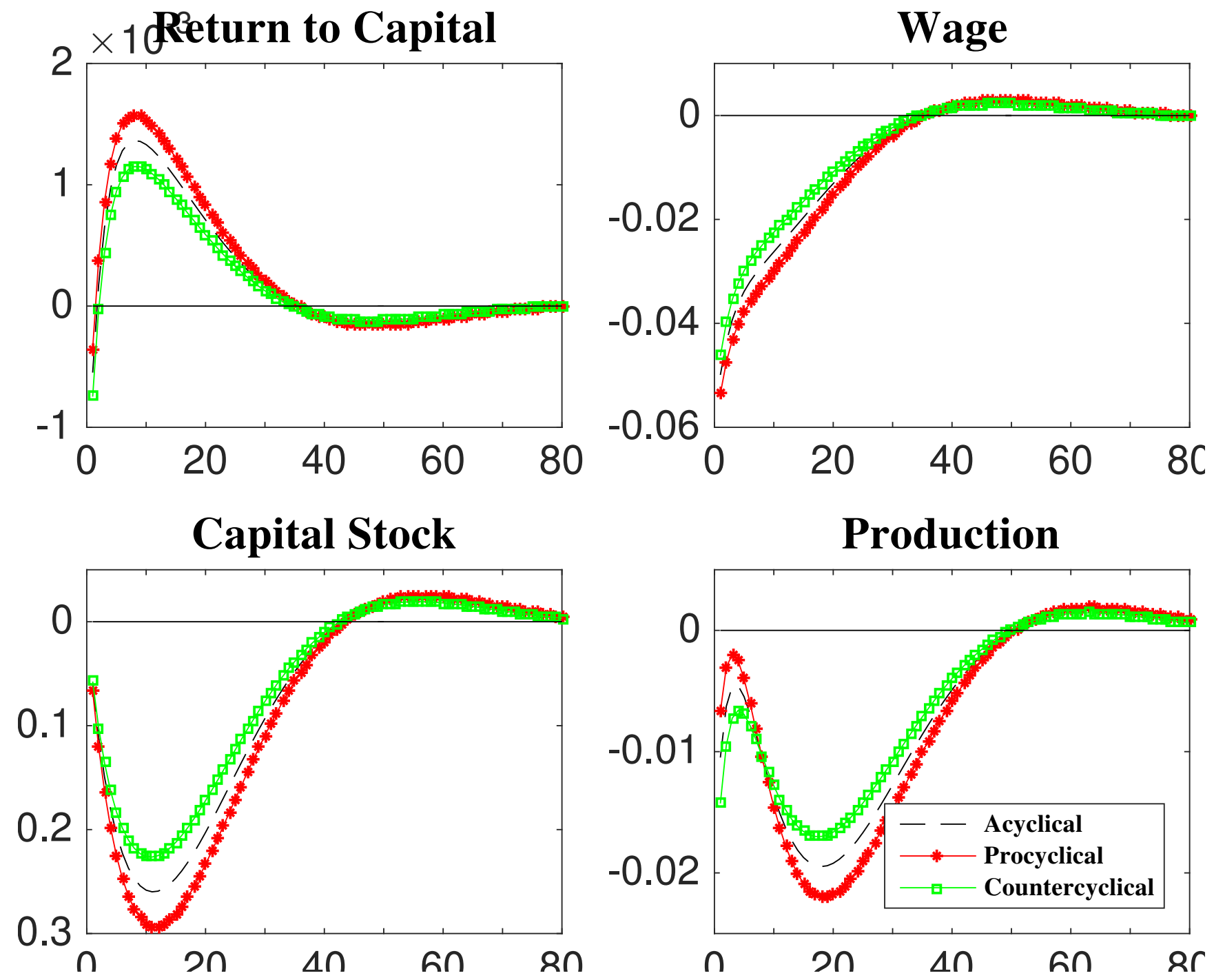

Figure 4: Average stochastic path following negative TFP shock under different policy regimes. 
aggregate/macro variables allows us to interpret them as the consequences for national (including sovereign) default. Nevertheless, what this underlines is the need for any such renegotiation to be accompanied by a business plan for the debtors (Greece), indicating how they can use additional funding to grow their way out of their (temporary) hole. A second requirement is for some commitment device to relate the release of additional funding (forgiveness) to the debtor (Greece) to their application of such extra funds to the business plan as originally developed and agreed between debtor and creditor. Put differently, we require that the business plan is time consistent and individually rational. More importantly this plan needs not to be imposed by the creditors but, rather, voluntarily be adopted and committed to fully by the debtors.

The need to come up with such a business plan, and conditionality in releasing funds if, and only if, such plans are carried out, is a commonplace in cases of commercial bankruptcy; but we believe that we are original both in relating this to current Greek sovereign renegotiation, and in doing so in a rigorous model, outlining formally and mathematically the various costs and benefits of default and renegotiation. ${ }^{22}$

If such conditions can be met, we would then argue that immediate restructuring that reduces the present value of debt, would benefit both Greece as well as its creditor countries over the medium and long term ${ }^{23}$

\footnotetext{
${ }^{22}$ Indeed, the argument that restructuring is synonymous with default was put forward by Tsomocos in 2011 on the day of the restructuring of Greek debt ("Skai News Channel", Interview, 27 October, 2011).

${ }^{23}$ What the Greek people wanted during these years was some combination of three conditions, (i) to stay in the euro, (ii) a lower debt burden, and (iii) less austerity. Because the desire of the Greek people to stay in the euro was even stronger than the German wish to keep them in the single currency, (Schauble would have been willing to allow Greece a (temporary) exit from the euro), the threat from the Greek side to cause a contagious crisis by exiting became increasingly weaker.
} 


\section{2nd Order Approximation}

In this section we show the results of a higher order approximation of the economy. We consider the Acyclical, Countercyclical and Procyclical policies from Section 4 as well as:

Lenient to Harsh $(\mathrm{LtoH}): \rho^{k}=-.2 \rho^{A}, u_{t}^{\kappa}=10 u_{t}^{A}$. and

Harsh to Lenient (HtoL): $\rho^{k}=.2 \rho^{A}, u_{t}^{\kappa}=-10 u_{t}^{A}$.

The Lenient to Harsh regime generates a large negative response to the recovery rate when a negative TFP shock hits, and in subsequent periods is higher than steady state levels, tracking the (negative) path of the TFP process. The Harsh to Lenient imposes strict conditions when TFP is low but then subsequently is more lenient.

\subsection{Calibration}

Our calibration is identical to the previous section, apart from a smaller volatility of the TFP shock process. This was necessary to guarantee convergence of the dynamical system at the 2nd order approximation level. The standard deviation of the shock $\left(u_{A}\right)$ is $.212 \%$ in Angelopoulos et al. (2010) however we set it to be fifty times lower in order to obtain a 2nd order approximate solution to our economy. As a result, the standard deviation of Greek default rates in our economy is . $31 \%$,

Table 4 lists values and sources for values different from the 1st order case (Table 1). 


\begin{tabular}{ccccc}
\hline Parameter & Description & Model Value & Source Value & Reference \\
\hline \hline$u_{A}$ & Standard Deviation of TFP Shock & $0.00424 \%$ & $.212 \%$ & Angelopoulos et al. (2010) \\
$E\left(R_{t}^{u}-1\right)$ & Mean Annual Unsecured interest rate & $12.32 \%$ & $12.81 \%$ & St.Louis/FRED \\
$E($ def $)$ & Mean default rates & $5 \%$ & $3.1 \%$ & S\&P \\
$S t D($ def $)$ & Variance of default rates & $.31 \%$ & $3.46 \%$ & S\&P \\
Vrugt $(2011)$ & & & \\
\hline \hline
\end{tabular}

Table 4: List of Calibrated Values

\subsection{Business Cycle Properties}

In this section ${ }^{24}$ we first simulate the 2 nd order approximate version stochastic steady-state of the economy and study the business cycle properties of our economy. Then we examine the impulse responses of four policy regimes.

\subsubsection{Simulated Economy}

Table 5 shows the moments of key variables in our economy. The columns correspond to the three scenarios just described. When there is forgiveness $(\mathrm{TFP}+$ Forg), the volatility of German and Greek consumption, is lower, as is the correlation of German consumption with Greek production. Default rates are also strongly counter-cyclical in the baseline case, but decrease in absolute value from a correlation with Greek GDP of -.599 in the baseline case to -.3844 when there is forgiveness. The stock of debt, particularly the unsecured type, and the capital stock both become more pro-cyclical when there is forgiveness showing that forgiveness allows the economy to grow out of low income environments.

\footnotetext{
${ }^{24}$ Numerical calulations were performed in Dynare. We consider deviations from the level.
} 


\begin{tabular}{|c|c|c|c|c|c|c|c|c|c|c|}
\hline & \multicolumn{4}{|c|}{ Mean } & \multicolumn{6}{|c|}{ Standard Deviation } \\
\hline & Acyc & Pro & Countc & LtoH & HtoL & Acyc & Pro & Countc & LtoH & HtoL \\
\hline$\overline{R_{t}^{s}-1}$ & 0.0050 & 0.0050 & 0.0050 & 0.0050 & 0.0050 & 0.0008 & 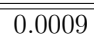 & 0.0008 & 0.0007 & $\overline{0.0011}$ \\
\hline$R_{t}^{u}-1$ & 0.0308 & 0.0308 & 0.0308 & 0.0308 & 0.0308 & 0.0002 & 0.0003 & 0.0002 & 0.0002 & 0.0003 \\
\hline$d e f^{G R C}$ & 0.0501 & 0.0502 & 0.0502 & 0.0502 & 0.0502 & 0.0031 & 0.0041 & 0.0044 & 0.0042 & 0.0043 \\
\hline$R^{k}-1$ & 0.0273 & 0.0273 & 0.0273 & 0.0273 & 0.0273 & 0.0001 & 0.0001 & 0.0001 & 0.0001 & 0.0001 \\
\hline$c_{a p}^{G R C}$ & 6.4972 & 6.4971 & 6.4968 & 6.4968 & 6.4971 & 0.0219 & 0.0243 & 0.0188 & 0.0183 & 0.0247 \\
\hline$c^{G E R}$ & 1.1765 & 1.1765 & 1.1764 & 1.1764 & 1.1765 & 0.0034 & 0.0039 & 0.0029 & 0.0027 & 0.0040 \\
\hline$c^{G R C}$ & 0.8311 & 0.8311 & 0.8311 & 0.8311 & 0.8311 & 0.0009 & 0.0010 & 0.0007 & 0.0007 & 0.0010 \\
\hline$b_{s}$ & 0.8667 & 0.8667 & 0.8666 & 0.8666 & 0.8667 & 0.0025 & 0.0028 & 0.0022 & 0.0021 & 0.0028 \\
\hline$b_{u}$ & 0.4304 & 0.4278 & 0.4264 & 0.4270 & 0.4271 & 0.0452 & 0.0498 & 0.0391 & 0.0378 & 0.0508 \\
\hline$W^{G E R}$ & 30.1534 & 30.1503 & 30.1462 & 30.1468 & 30.1496 & 0.0374 & 0.0413 & 0.0323 & 0.0313 & 0.0348 \\
\hline \multirow[t]{3}{*}{$W^{G R C}$} & -23.0838 & -23.0814 & -23.0798 & -23.0804 & -23.0808 & 0.0310 & 0.0340 & 0.0268 & 0.0258 & 0.0021 \\
\hline & \multicolumn{4}{|c|}{ Correlation with Production } & \multicolumn{6}{|c|}{$\begin{array}{l}\text { First Order Auto-correlation } \\
\end{array}$} \\
\hline & Acyc & Pro & Countc & LtoH & HtoL & Acyc & Pro & Countc & LtoH & HtoL \\
\hline$\overline{R_{t}^{s}-1}$ & "0.3904 & 0.3421 & "0.4697 & 0.4729 & 0.3317 & 0.9387 & 0.9451 & 0.8874 & 0.9504 & 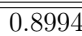 \\
\hline$R_{t}^{u}-1$ & -0.5893 & -0.5483 & -0.6627 & -0.6501 & -0.5470 & 0.9751 & 0.9756 & 0.9583 & 0.9819 & 0.9562 \\
\hline$d e f^{G R C}$ & -0.7349 & -0.5323 & -0.6161 & -0.6149 & -0.5446 & 0.9796 & 0.5748 & 0.5234 & 0.4284 & 0.5593 \\
\hline$R^{k}-1$ & -0.7502 & -0.7405 & -0.7555 & -0.7221 & -0.7653 & 0.9722 & 0.9802 & 0.9531 & 0.9512 & 0.9806 \\
\hline $\operatorname{cap}^{G R C}$ & 0.9127 & 0.9000 & 0.9338 & 0.9196 & 0.9110 & 0.9951 & 0.9953 & 0.9943 & 0.9949 & 0.9949 \\
\hline$c^{G E R}$ & 0.4485 & 0.4843 & 0.3783 & 0.3851 & 0.4744 & 0.9109 & 0.9109 & 0.8954 & 0.9191 & 0.8931 \\
\hline$c^{G R C}$ & 0.0518 & 0.0084 & 0.1352 & 0.1458 & 0.0114 & 0.9122 & 0.9128 & 0.9026 & 0.9162 & 0.9028 \\
\hline$b_{s}$ & 0.9542 & 0.9555 & 0.9355 & 0.9436 & 0.9573 & 0.9943 & 0.9947 & 0.9893 & 0.9954 & 0.9898 \\
\hline$b_{u}$ & 0.9520 & 0.9471 & 0.9613 & 0.9514 & 0.9536 & 0.9964 & 0.9966 & 0.9956 & 0.9961 & 0.9963 \\
\hline$W^{G E R}$ & 0.9224 & 0.9104 & 0.9451 & 0.9337 & 0.9195 & 0.9938 & 0.9946 & 0.9921 & 0.9930 & 0.9941 \\
\hline$W^{G R C}$ & -0.9695 & -0.9716 & -0.9670 & -0.9547 & -0.9765 & 0.9964 & 0.9962 & 0.9963 & 0.9961 & 0.9965 \\
\hline
\end{tabular}

Table 5: Business Cycle Properties of Simulated Economy 


\subsection{Conditional Welfare Analysis}

Table 6 below presents the immediate deviations from steady state welfare, following a negative shock to TFP (the conditional welfare, as described in Schmitt-Grohe and Uribe (2004)) ${ }^{25}$. As the values below are the deviations from the steady state of the value function (defined recursively, as standard), these values represent the total welfare loss under the different policy regimes following a negative TFP shock. The Lenient-to-Harsh policy dominates for the welfare evaluation of Germany. For Greece it is dominated by the Countercyclical policy and Harsh-to-Lenient policy. As actual policy followed either the Acyclical, or more likely the Procyclical policy, we surmise that a Pareto improvement would have been possible under an Lenient-to-Harsh policy.

\begin{tabular}{llllll} 
& Acyclical & $\begin{array}{l}\text { Pro- } \\
\text { cyclical }\end{array}$ & $\begin{array}{l}\text { Counter- } \\
\text { cyclical }\end{array}$ & $\begin{array}{l}\text { Lenient-to- } \\
\text { Harsh }\end{array}$ & $\begin{array}{l}\text { Harsh-to- } \\
\text { Lenient }\end{array}$ \\
\hline $\mathbb{E}\left\{W^{G E R} \mid 0\right\}$ & -0.0034 & -0.0033 & -0.0036 & -0.0032 & -0.0037 \\
$\mathbb{E}\left\{W^{G R C} \mid 0\right\}$ & -0.0003 & -0.0006 & 0.0002 & -0.0003 & -.0001 \\
\hline \hline
\end{tabular}

Table 6: Conditional Welfare Analysis

\footnotetext{
${ }^{25}$ As the non-stochastic steady state is the same across the policy regimes, we can calculate welfare conditional on being on the initial state being the non-stochastic steady state. Hence the subsequent deviations from it will derive from the different policy environments chosen. In contrast, using an unconditional welfare measure is problematic as the stochastic steady states are different under the different policy regimes and does not take into account the transitional dynamics leading to the stochastic steady state.
} 


\section{Simulations}

\subsection{Impulse Responses}

Figures 5 to 8 give the impulse responses following a negative TFP shock under the different policy regimes in the 2nd order approximate version of the model.

The Procyclical policy regime (green circled series) has much larger fluctuations than the other ones, driven by the larger immediate decline in Greek capital and consumption as a result of higher repayment requirements. In contrast, the Lenient-to-Harsh and Countercyclical policies insulate the Greek economy at the cost of an immediate fall in German Consumption. The Lenient-toHarsh policy regime results in higher immediate Greek default rates (as more of that is recovered) and a higher unsecured interest rate. This translates into a faster downward adjustment in the capital stock but also faster recovery from 10 quarters onwards.

\section{Concluding Remarks}

The underlying problem in Greece is that no one has yet established a convincing program for reinvigorating growth. The Greek people and their transient governments argue, correctly, that greater austerity simply drives GDP further down, if anything worsening the debt overhang. The German people, and their government, fear that easing up on fiscal austerity would simply allow more consumption, more hand-outs to cronies, or inefficient investment. Austerity, they feel, could help to protect their creditor claims against the prospect of an unending stream of transfer payments, and loss of value. 

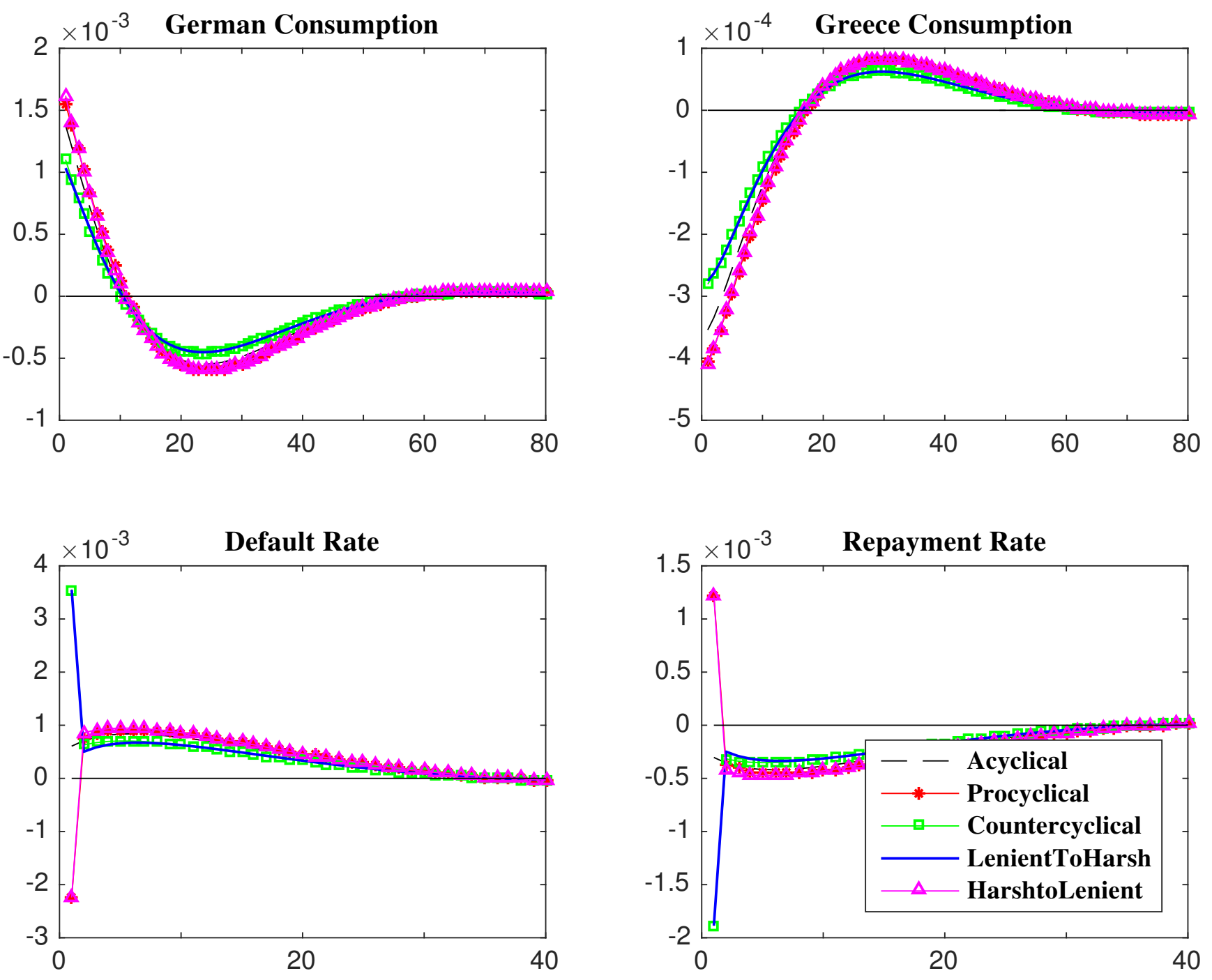

Figure 5: Average stochastic path following negative TFP shock under different policy regimes. Welfare is the conditional welfare series. 

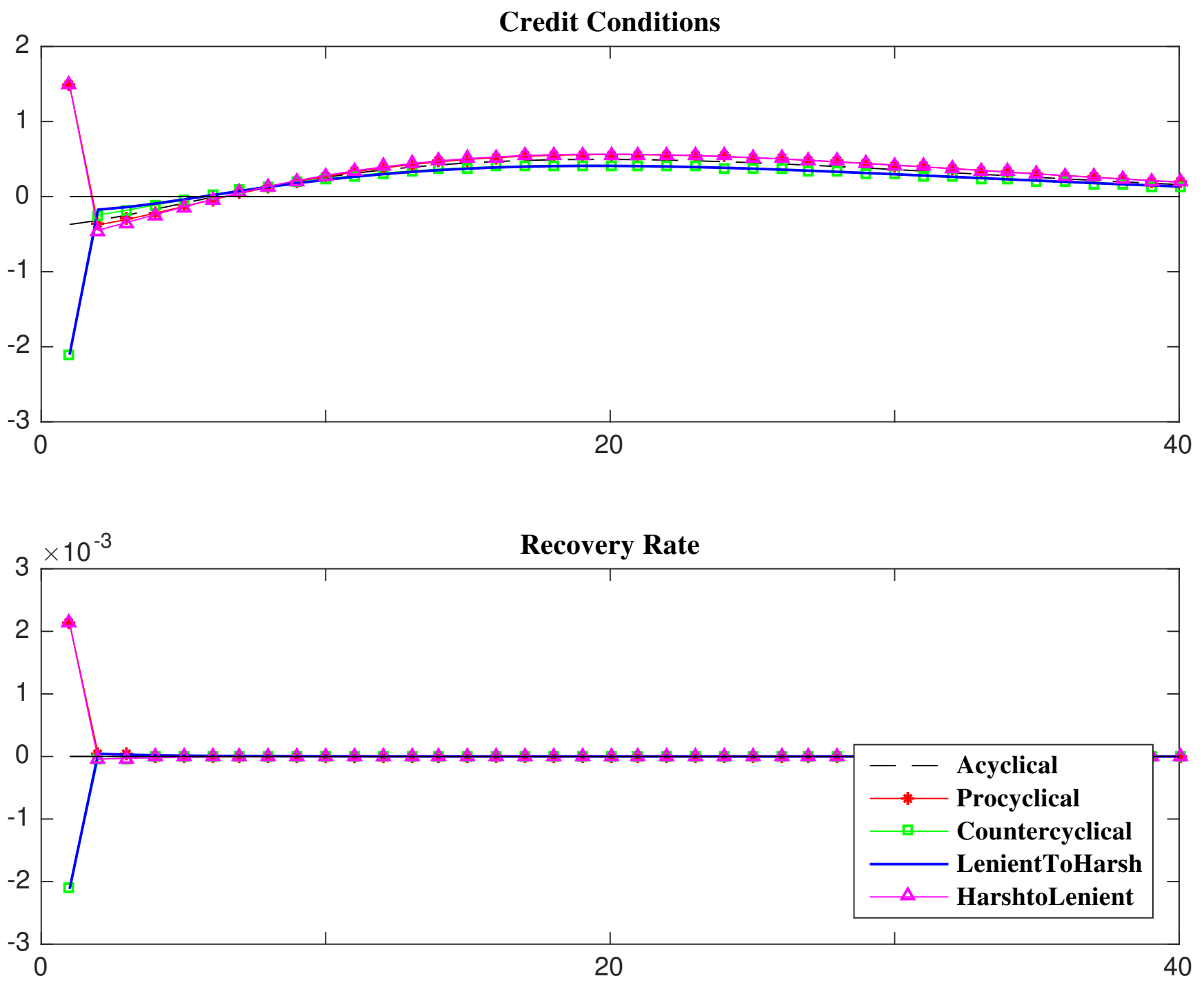

Figure 6: Average stochastic path following negative TFP shock under different policy regimes. 

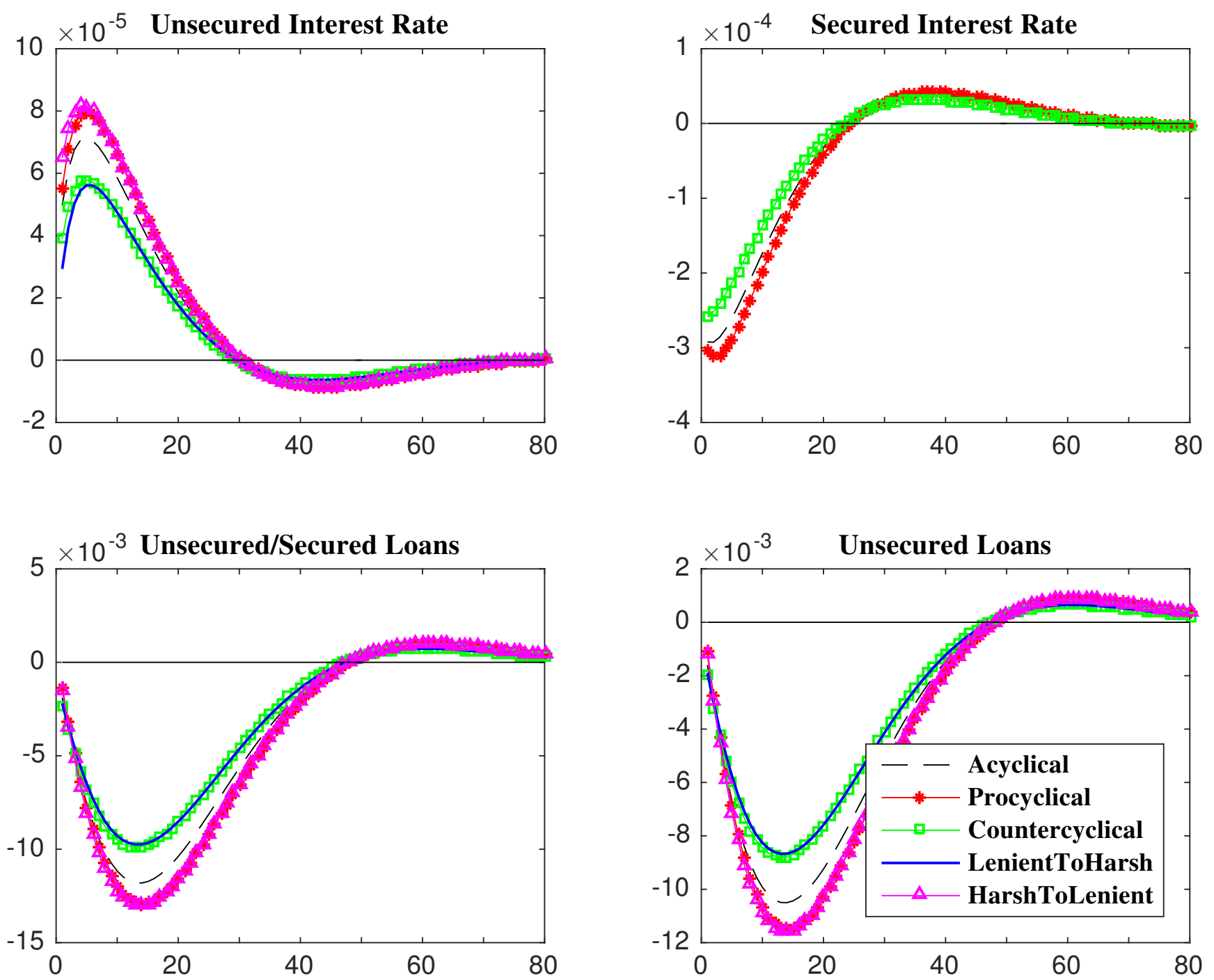

Figure 7: Average stochastic path following negative TFP shock under different policy regimes. 

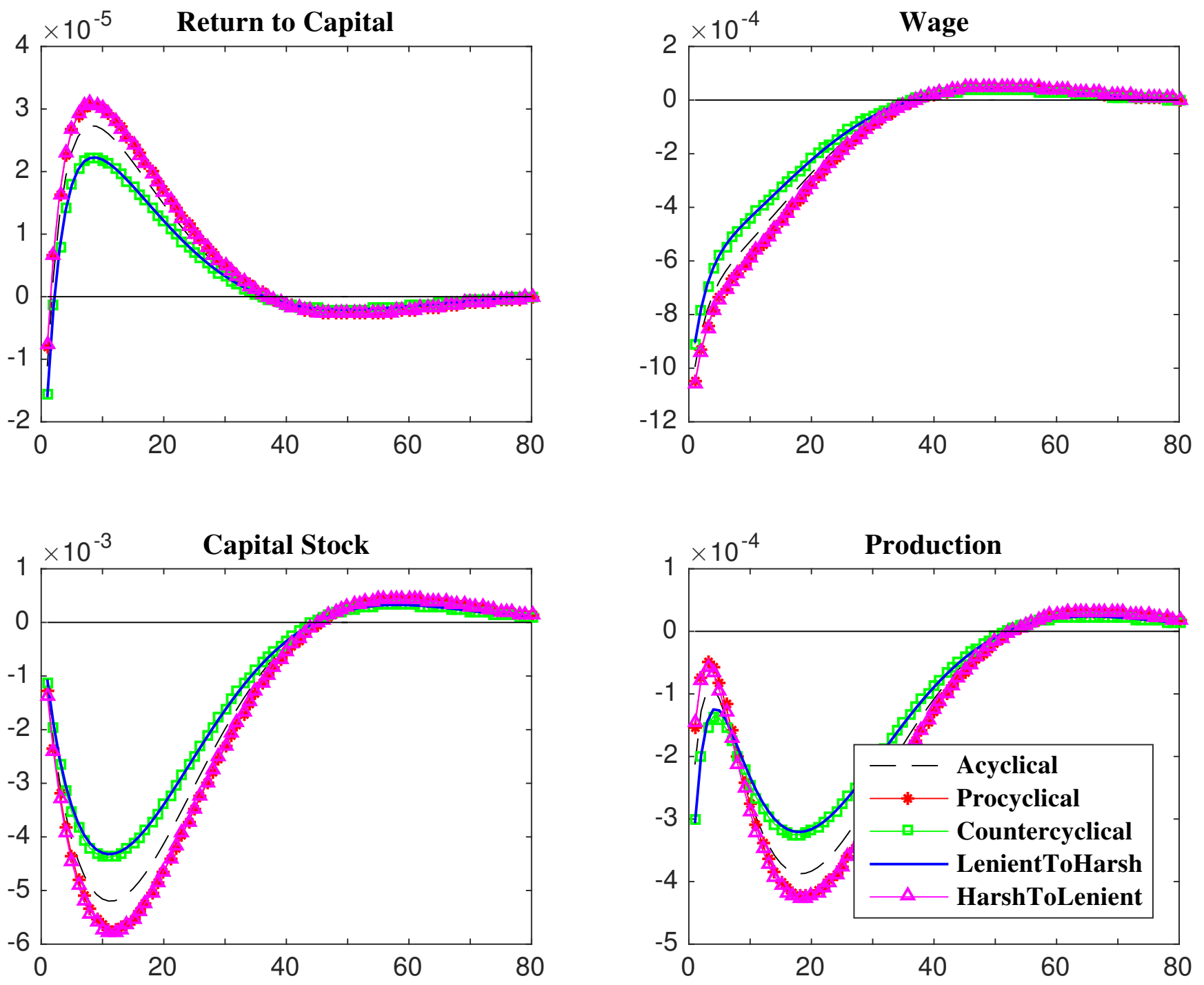

Figure 8: Average stochastic path following negative TFP shock under different policy regimes. 
We have assumed that an easier initial relaxation of policy regime would bring forth more efficient investment and faster growth, and that an incentive scheme could be established to ensure that there was no future back-sliding. If so, it would, of course, benefit both Germans and Greeks to follow this course. $^{26}$

While this can be, and most probably will be, dismissed as no more than wishful thinking, what we do conclude is that the main lacuna in all the negotiations has been a realistic and practical plan for the future growth of the Greek economy. If ever there was a place and time for a National Plan, it would surely be in Greece now.

\section{References}

Aguiar, Mark and Gita Gopinath (2006), 'Defaultable debt, interest rates and the current account', Journal of International Economics 69(1), 64-83. 4.3

Angelopoulos, Konstantinos, Sophia Dimeli, Apostolis Philippopoulos, Vanghelis Vassilatos et al. (2010), Rent-seeking competition from state coffers in greece: a calibrated dsge model, Technical report. 4.1, ??, ??, ??, ??, ??, ??, 5.1, ??

Ardagna, Silvia and Francesco Caselli (2014), 'The political economy of the

\footnotetext{
${ }^{26}$ We have assumed that Greek households invest their resources into either consumption or investment. If national income is also used to finance public goods, such as healthcare, which are below efficient levels, then the extent of forgiveness required to stimulate investment increases. Furthermore, the path of public goods expenditure over the business cycle will affect investment through the intertemporal Euler equation. These important considerations have not been examined here as they will affect the quantitative rather than qualitative nature of our results.
} 
greek debt crisis: A tale of two bailouts', American Economic Journal: Macroeconomics 6(4), 291-323. 1

Arellano, Cristina (2008), 'Default risk and income fluctuations in emerging economies', American Economic Review 98(3), 690-712. 4.3

Asonuma, Tamon and Christoph Trebesch (2016), 'Sovereign debt restructurings: Preemptive or post-default', Journal of the European Economic Association 14(1), 175-214. 7

Benjamin, D. and J. Wright, M. (2013), Recovery before redemption: A theory of delays in sovereign debt renegotiations. 1, 18, 4.1

Bitzenis, A., N. Karagiannis and J. Marangos (2015), Europe in Crisis: Problems, Challenges, and Alternative Perspectives, Palgrave Macmillan. 2

Bortz, Pablo G. (2015), 'The greek "rescue": Where did the money go? an analysis', Institute for New Economic Thinking Working Paper 29. 9

Broner, Fernando, Aitor Erce, Alberto Martin and Jaume Ventura (2014), 'Sovereign debt markets in turbulent times: Creditor discrimination and crowding-out effects', Journal of Monetary Economics 61, 114 - 142. 1

De Walque, Gregory, Olivier Pierrard and Abdelaziz Rouabah (2010), 'Financial (in)stability, supervision and liquidity injections: A dynamic general equilibrium approach*', The Economic Journal 120(549), 1234-1261. 1

Dubey, P., J. D. Geanakoplos and M. Shubik (2005), 'Default and punishment in general equilibrium', Econometrica 73. 1, 2.2 
Eaton, J. and M. Gersovitz (1981), 'Debt with potential repudiation: theoretical and empirical analysis', The Review of Economic Studies 48, 289-309. 1

Geanakoplos, J. D. and W. Zame (2014), 'Collateral equilibrium, i: a basic framework', Economic Theory 56, 443-492. 15

Goodhart, C. A. E., M. U. Peiris and D. P. Tsomocos (2013), 'Global imbalances and taxing capital flows', International Journal of Central Banking June. 1

Goodhart, C. A. E., P. Sunirand and D.P. Tsomocos (2006), 'A model to analyse financial fragility', Economic Theory 27, 107-142. 1

Goodhart, C.A.E., P. Sunirand and D.P. Tsomocos (2005), 'A risk assessment model for banks', Annals of Finance (1), 197-224. 1

Gourinchas, Pierre-Olivier, Thomas Philippon and Dimitri Vayanos (2016), The Analytics of the Greek Crisis, University of Chicago Press. 1, 4

Karmann, Alexander and Dominik Maltritz (2012), 'Sovereign default risk and recovery rates: What government bond markets expect for greece', Review of International Economics 20(4), 723-739. 4.1, ??

Kiyotaki, Nobuhiro and John Moore (1997), 'Credit cycles', Journal of Political Economy 105(2), 211-48. 15

Peiris, M. Udara and Dimitrios P. Tsomocos (2015), 'International monetary equilibrium with default', Journal of Mathematical Economics 56, 47 - 57. 1 
Roch, Francisco and Harald Uhlig (2016), 'The dynamics of sovereign debt crises and bailouts', IMF Working Paper 16/136. 1

Schmitt-Grohe, Stephanie and Martin Uribe (2004), Optimal simple and implementable monetary and fiscal rules, Working Paper 10253, National Bureau of Economic Research. 5.3

Shubik, M and C. Wilson. (1977), 'The optimal bankruptcy rule in a trading economy using fiat money', Journal of Economics 37, 337-354. 1

Sturzenegger, Federico and Jeronim Zettelmeyer (1996), 'Defaults in the 90s', mimeo $\cdot 1.2$

Tsomocos, D. P. (2003), 'Equilibrium analysis, banking and financial instability', Journal of Mathematical Economics 39, 619-655. 1

Vrugt, Evert B (2011), 'Estimating implied default probabilities and recovery values from sovereign bond prices', The Journal of Fixed Income 21(2), 5-14. 4.1, ??, ??

Walsh, Kieran (2015a), Portfolio choice and partial default in emerging markets: A quantitative analysis. 1, 2.2

Walsh, Kieran (2015b), A theory of portfolio choice and partial default. 1, 2.2

Yue, Vivian Z. (2010), 'Sovereign default and debt renegotiation', Journal of International Economics 80(2), 176 - 187. 1

Zettelmeyer, Jeromin, Christoph Trebesch and Mitu Gulati (2013), 'The greek debt restructuring: an autopsy', Economic Policy 28(75), 513-563. 1, 8 